\title{
Batucadas, enredos e carnavalização. Os passos da Escola de Samba Nenê da Vila Matilde (1954-1967)
}

\begin{abstract}
Resumo
Neste texto, são discutidos aspectos da trajetória da Escola de Samba Nenê da Vila Matilde', de 1954 a 1967, centrando-se nos temas escolhidos para suas performances carnavalescas, com a intenção de detectar as possíveis pulsões críticas presentes nessas escolhas. Nesse sentido, a pesquisa argui se os motes de seus desfiles eram centrados apenas nas vivências do grupo ou se também dialogavam com os demais segmentos sociais. Traçar o seu perfil, nesse período de criação e consolidação das agremiações carnavalescas da comunidade negra, implica situá-la no grupo maior, de igual natureza, cujo percurso tem início em 1937, com o surgimento da "Lavapés", considerada a primeira escola de samba paulistana. Embora a "Nenê" tenha sido criada em 1949, o marco dessa reflexão tem início em 1954, por suas passeatas expressarem um padrão temático em suas exibições; e estende-se até 1967, ano que antecede a institucionalização pelo poder público dos desfiles carnavalescos na capital paulista, a partir de quando passou a haver investimento de recursos públicos em sua montagem e nas escolas de samba. A pesquisa apoiou-se na imprensa diária, nos memorialistas (autobiografia, fotos e depoimentos dessas lideranças carnavalescas) e na bibliografia pertinente, buscando detectar os traços dessa Escola antes de sua institucionalização.

Palavras-chave: Brasil; Escolas de Samba paulistanas; Carnavais Negros; Samba-Enredo; Nenê da Vila Matilde.
\end{abstract}

Palavras-chave: Carnaval; Escolas de samba - São Paulo; Negros; Nenê da Vila Matilde (escola de samba); Samba.

\section{Para citar este artigo:}

SILVA, Zélia Lopes. Batucadas, enredos e carnavalização. Os passos da Escola de Samba Nenê da Vila Matilde (1954-1967). Revista Tempo e Argumento, Florianópolis, v. 8, n. 18, p. 351 - 384. maio/ago. 2016.

\section{DOI: 10.5965/2175180308182016351}

http://dx.doi.org/10.5965/2175180308182016351

1 O nome da Escola funde-se ao apelido de seu presidente, Alberto Alves da Silva, conhecido por Nenê da Vila Matilde. Em suas memórias, porém, ele afirma não ser o responsável pela indicação, e sim Mário Protestato dos Santos (Popó), jornalista de O Dia, que estava presente na União das Escolas de Samba de São Paulo quando proponentes da associação foram comunicar a intenção de criar uma escola de samba. Eles eram músicos e batuqueiros que se reuniam, com frequência, no Largo do Peixe, no bairro de Vila Matilde, na Zona Leste de São Paulo. Desde o final de 1948 discutiam o assunto, mas somente formalizaram a intenção em $1^{\circ}$ de janeiro de 1949 , sem pensar o nome da entidade. Na UESP, o grupo viveu o impasse dessa escolha. Seu Nenê conta que ficara afastado, calado, tocando o seu pandeiro, sem querer entrar na polêmica. Popó, desconhecido para o grupo, pergunta quem era aquele sujeito e, ao saber que era conhecido por Nenê da Vila Matilde, sugeriu que a escola assim fosse chamada. A brincadeira, conta Seu Nenê, consagrou o seu apelido em epígrafe para designar a escola de samba de seu bairro (SILVA, BRAIA, 2000, p. 48-49). 


\title{
Drumming, plots and
} carnivalization. The steps of Nenê da Vila Matilde Samba School

\section{(1954-1967)}

\begin{abstract}
This paper discusses aspects of Nenê da Vila Matilde ${ }^{2}$ Samba School trajectory's, between 1954-1967, focusing on the themes chosen for their carnival performances with the intention of detecting possible critical drives in those choices. In this sense, the research examines whether the themes of their parades were focused only on the experiences of the group or if they also were connected with other social segments. Tracing it's profile in this creation period and consolidation of black community's carnival groups implies to place it in the larger group of the same kind, whose journey begins in 1937 with the "Lavapés" emerging, considered the first São Paulo's samba school. Although "Nenê" was created in 1949, the landmark of this image begins in 1954 as their marches express a default theme on their views. And it extends until 1967, one year before the institutionalization of carnival parades by São Paulo's government, investing public funds in their assembly and samba schools. The research relied on daily press, memoir writers (autobiography, photos, testimonies of those carnival leaders) and the relevant literature, trying to detect the traces of this School before that institutionalization.
\end{abstract}

Keywords: Brazil; Carnivals; Samba Schools of São Paulo; Black; Samba-Enredo; Nenê da Vila Matilde.

\footnotetext{
${ }^{2}$ The name of the School merges into the name of its president, Alberto Alves da Silva, known as Nenê da Vila Matilde. In his memoirs, however, he claims not to be responsible for the appointment it was Mário Protestato dos Santos (Popó), journalist of O Dia, who was present at the Union of São Paulo Samba Schools when association proponents were communicating the intention to create a samba school. They were musicians and drummers who met often at Largo do Peixe, in the Vila Matilde neighborhood in the East Zone of São Paulo. Since late 1948 they discussed the matter, but only formalized the intention on January 1, 1949, without thinking about the organization name. In UESP, the group experienced the impasse of that choice. Mr. Nenê says that he had been away, silent, playing his tambourine, not wanting to get into the controversy. Popó, unknown to the group, asked who that person was and discovering that his name was Nenê da Vila Matilde (nickname), suggested that the school should have his name. The joke, says Mr. Nenê, consecrated his nickname the title to designate the samba school of their neighborhood (SILVA, BRAIA, 2000, p. 48-49)
} 


\section{Introdução}

“O presente sem passado não anda muito longe." (Seu Nenê) ${ }^{3}$

Discutir os temas trazidos pelas escolas de samba paulistanas antes da oficialização dos carnavais na cidade, ocorridos em 1968, é desafiante. A escassez de registros, na imprensa diária e demais fontes, sobre a estruturação dos desfiles carnavalescos dessas agremiações que são exibidos nas ruas é realçada pela bibliografia especializada, muito embora ocorram crônicas breves dessas apresentações e, aqui e acolá, algumas fotos de suas performances. Em decorrência disso, torna-se difícil (mas não impossível) reconstruir os motes das exibições dessas escolas de samba no decurso dos anos, buscando os sentidos dessas encenações, as visões de mundo de seus integrantes expressas nas escolhas de seus trajes, no gestual, nas alegorias e nas pândegas diversas que invertem valores e consagram outros, utilizando-se do exagero e do riso para construir uma nova ordem, pelo menos nos dias dedicados a Momo, deus da galhofa e da zombaria.

Chegar às propostas dessas agremiações significa vencer obstáculos, pela ausência de informações de todo tipo: estrutura dos desfiles, descrição do que era exibido pelos pândegos; tipo de trajes usados no desenvolvimento dos temas; imprecisão e divergências em relação aos marcos iniciais de alguns cordões cuja matriz é o samba. Ao transformarem os cordões em escolas de samba, essas origens são deixadas à margem ${ }^{4}$,

\footnotetext{
3 Trata-se de Alberto Alves da Silva, conhecido pelo apelido de Nenê da Vila Matilde, que foi Presidente da Escola de Samba de mesmo nome, localizada na cidade de São Paulo, de sua criação, em 1949, ao ano de 1996, quando passou o comando para o seu filho Alberto Alves da Silva Filho. O Seu Nenê, após a sua morte, continuou como Presidente de Honra da Escola.

${ }^{4}$ Esta questão da origem se estende ao Vai-Vai (1930) e ao Camisa Verde e Branco (1914), que eram cordões que mantiveram essa nomenclatura até se transformarem em escolas de samba, no início da década de 1970. As informações são desencontradas sobre essa transformação. Em suas memórias, Seu Nenê cita o ano de 1973 (SILVA, BRAIA, 2000, p. 54). Já de acordo com o depoimento de Sebastião Amaral (Pé Rachado, que foi presidente da atual Vai-Vai), guardado no MIS/SP, essa transformação ocorreu em 1971, data que será considerada neste texto. Deve-se considerar que estamos no campo da memória e essa precisão não tem tanta importância. Ambos protagonizaram os principais eventos carnavalescos do grupo como dirigentes de suas respectivas agremiações, e deram os seus depoimentos já bastante idosos, embora lúcidos, o que dificulta lembrar datas de situações recuadas no tempo.
} 
Este texto visa refletir sobre as performances da Escola de Samba Nenê da Vila Matilde, criada doze anos depois da emergência da Lavapés, inserindo-a no contexto das associações, já existentes, dedicadas ao samba. Lembra Seu Nenê que ele e um grupo de amigos $^{6}$ — Tóquio, Juvenal, Balduíno, José Brito Laurindo, Didi, Getúlio, Julião, Expedito, Livino, Benedito Justino, a irmã Geraldina e Manolo - , ao criarem a Escola de Samba Nenê da Vila Matilde, em 1949, o cenário paulistano já se alterara com a presença de várias agremiações dedicadas ao samba. As reflexões neste artigo, contudo, voltam-se aos temas e sambas-enredo que organizaram os seus desfiles, de 1954 a 19677, os quais conferem relevância à Escola em relação às demais agremiações existentes. Os seus motes voltam-se ao universo sociopolítico referente ao grupo ou ao país, mesmo considerando os limitados recursos financeiros para exibições mais acuradas de propostas que exigem alegorias e formas escultóricas, que se inscrevem em universo de conhecimento fora do mundo do samba ${ }^{8}$.

O texto termina em 1967, por ser o último ano de encenações das escolas de samba estruturadas sem interferência financeira do poder público municipal da capital paulista. A partir de 1968, com a oficialização desses festejos, as agremiações passaram a receber verbas para estruturação dos desfiles (BARONETTI, 2013).

\footnotetext{
${ }^{5}$ Alberto Alves da Silva (Seu Nenê da Vila Matilde) diz que a Escola de Samba Lavapés teria surgido em 1933, e não em 1937, quando aquela Escola foi criada. A referência de Seu Nenê é a criação do Cordão Baianas Teimosas, atribuindo sua transformação na Escola de Samba Lavapés. Porém, sabe-se que Lavapés foi criada em 1937. O cordão Baianas Teimosas, também chamado de Baianas Paulistas, organizado por mulheres em 1932, incorpora-se à Escola de Samba Lavapés, em 1939, conforme Madrinha Eunice, que a dirigiu por longos anos, em depoimento depositado no Museu da Imagem e do Som/SP. Essa dificuldade também se aplica à origem das escolas que, de acordo com algumas falas, têm como ano de criação o primeiro desfile, gerando desencontros de datas (Fita 112.25 - Carnaval Paulistano - MIS/SP - Deolinda Madre (Madrinha Eunice)).

${ }^{6}$ Os fundadores da "Nenê", segundo o seu Presidente, foram as seguintes pessoas: "Éramos 13 - eu, Tóquio, Juvenal, Balduíno, José Brito Laurindo, Didi, Getúlio, Julião, Expedito, Livino, Benedito Justino, minha irmã Geraldina e o Manolo - cinco pretinhos e o resto todos brancos, mas tudo branco bom de samba" (SILVA, BRAIA, 2000, p. 48).

7 O fato de as escolas de samba se exibirem durante o carnaval não significa confundir samba e carnaval, bem como minimizar o papel desempenhado por essas agremiações, no âmbito da comunidade, durante $o$ ano inteiro. Esse assunto já foi amplamente debatido pelos pesquisadores desde o surgimento dos primeiros cordões.

${ }^{8}$ Exemplos dessas limitações se manifestam nas dificuldades financeiras para o pagamento antecipado das "alegorias" aos artistas plásticos/escultores, conforme menciona Seu Nenê (SILVA, BRAIA, 2000, p. 58), que viveu essa experiência.
} 
A mudança de rumo (atendendo as demandas das diversas associações carnavalescas da cidade que solicitaram a oficialização desses festejos, como relata Seu Nenê) requer a agregação das escolas de samba numa entidade única, o que significa criar novamente uma associação centralizadora de todos os agrupamentos carnavalescos. Surge, então, a União das Escolas de Samba Paulistanas (UESP), em 1973, com a finalidade de agregar as escolas de samba e blocos carnavalescos e representá-los junto ao poder público. Porém, Wilson de Moraes (1978) afirma que nesse processo também houve mudanças internas nas escolas, prevalecendo o modelo carioca para a estruturação de seus desfiles. O mesmo afirma Sebastião Amaral, do cordão Vai-Vai, que especifica, em depoimento, a estrutura do(s) cordão(ões) e o que mudou em sua transformação em escola de samba, assunto que será tratado posteriormente.

As dificuldades das pesquisas de temas dessa natureza, por limitações e ausência de registros, sempre foram contornadas quando o pesquisador pôde recorrer aos próprios protagonistas, como fizeram as sociólogas leda Marques Britto (1986), Olga von Simson (2007), o carnavalesco Wilson de Moraes (1978) e mais recentemente Bruno Sanches Baronetti (2013), que entrevistaram os integrantes das agremiações carnavalescas de seu interesse, recuperando, assim, os passos desses pândegos dos carnavais de rua, organizados sob a rubrica de escolas de samba, de então e de hoje. Simson, além dos depoimentos, conseguiu fotos dos arquivos pessoais dessas lideranças, dos desfiles dos antigos cordões e das escolas de samba, em particular as fotos da Escola de Samba Nenê da Vila Matilde. 9

$\mathrm{Na}$ pesquisa em questão, além dos jornais, os registros memoriais desses protagonistas, homens e mulheres, foram bastante significativos para elucidar as particularidades de algumas dessas agremiações. Arquivados em formato de depoimentos no Museu da Imagem e Som/SP - MIS, esses registros trazem as lembranças, sob sua perspectiva, dos principais protagonistas que estiveram envolvidos

\footnotetext{
9 A Escola de Samba Nenê da Vila Matilde apresentou seu primeiro desfile em 1949, mas parece que somente em 1954 os temas são recorrentes em seus desfiles, como mostram as fotos dessa agremiação, citadas por Olga von Simson (2007). Seu Nenê não menciona nenhum tema específico anterior à data aludida. Somente em 1956 é que foi criado o primeiro samba-enredo da "Escola de Samba Nenê da Vila Matilde" (e de São Paulo), com o tema Casa Grande e Senzala. Tornou-se a agremiação de maior projeção no período anterior a 1968, uma vez que os cordões Camisa Verde Branco e o Vai-Vai, presenças marcantes nos carnavais da cidade, ainda não haviam se transformado, oficialmente, em escolas de samba, o que somente aconteceu em 1971, conforme Sebastião Amaral.
} 
Alberto Alves da Silva (Seu Nenê). Este último, ao falar de sua trajetória carnavalesca e da própria escola, ainda traz, em rápidas pinceladas, informações sobre outros agrupamentos.

Sabe-se que essas recordações carregam elementos subjetivos e foram construídas em situações distintas (uma autobiografia e registros memorialísticos arquivados em banco de dados de história oral sobre o Carnaval Paulistano, do MIS/SP). Contudo, são lembranças que certamente omitem protagonistas, esquecem outros e projetam fatos corriqueiros, evidenciando situações fartamente debatidas pelos teóricos que se dedicam à narrativa oral ${ }^{10}$. Esses traços não são muito diferentes dos registros, lacunas e "esquecimento" da imprensa, cujos compromissos nem sempre passam pelos interesses de valorização das práticas culturais dos segmentos populares ${ }^{11}$. Assim, esses itinerários são delineados no decurso desse texto, bem como os possíveis sentidos do que foi apresentado nos desfiles de rua, considerando as questões apontadas sobre as fontes, suas subjetividades e lacunas.

\section{As escolas de samba: cartografia e perfis}

As notícias dos desfiles dessas associações voltadas ao samba são recorrentemente incompletas, muito embora seus nomes sejam listados pelos jornais, em alguns anos, durante os carnavais, a exemplo da Escola de Samba Nenê da Vila Matilde, que é presença constante nos desfiles de rua referentes a essas celebrações. Fundada em

\footnotetext{
${ }^{10}$ O material usado decorre de situações distintas de coleta - uma autobiografia e narrativas coletadas para integrar o banco de dados, Carnaval Paulistano/MIS -, a exemplo do que sistematiza Verena Alberti (2005, p. 175). A autora diz que as entrevistas são de dois tipos: a) entrevistas temáticas; ou b) histórias de vida (que recuperam a trajetória do entrevistado desde a infância até o momento em que fala). Esclarece, ainda, que "apesar das diferenças, ambos os tipos têm relação com o método biográfico: seja concentrando-se sobre um tema, seja debruçando-se sobre um indivíduo e os cortes temáticos efetuados em sua trajetória, a entrevista terá como eixo a biografia do entrevistado, sua vivência e sua experiência". No caso em questão, estão presentes as duas modalidades de registros.

${ }^{11}$ A imprensa produz um discurso que está longe de isenção de interesses, como argumentam os pesquisadores que abordam esses impressos. Tania Regina de Luca (2005), por exemplo, traz questões amplas sobre as contribuições e limites dessas fontes.
} 
janeiro de 1949, o seu primeiro desfile ocorre no mesmo ano. Os seus integrantes eram jovens, homens e mulheres, fantasiados de marinheiros, com suas camisas listradas, chapéus e, o mais importante, alguns dos componentes masculinos usavam acessórios femininos, e vice-versa. As fantasias são simples e despojadas, mas fazem uso de elementos caricatos buscando subverter a ordem, conforme analisam Propp ${ }^{12}$ e outros teóricos do riso e do humor. Em geral, os jovens do sexo masculino usam as clássicas camisas listradas e chapéus. Esse vestuário está associado ao marinheiro/malandro que não tem perfil comportado. As moças, três delas, portam roupas brancas e uma espécie de quepe (pequeno chapéu), indicando tratar-se de "comportadas marinheiras". Uma das pessoas, de traços delicados, à direita da foto, veste camisa listrada, tal qual os rapazes, usa brincos e uma discreta pulseira indicando tratar-se de travestimento (não importa o sexo; a inversão ocorre nas duas situações). No grupo, também há elementos de inversão entre os rapazes - dois deles portam chapéus femininos.

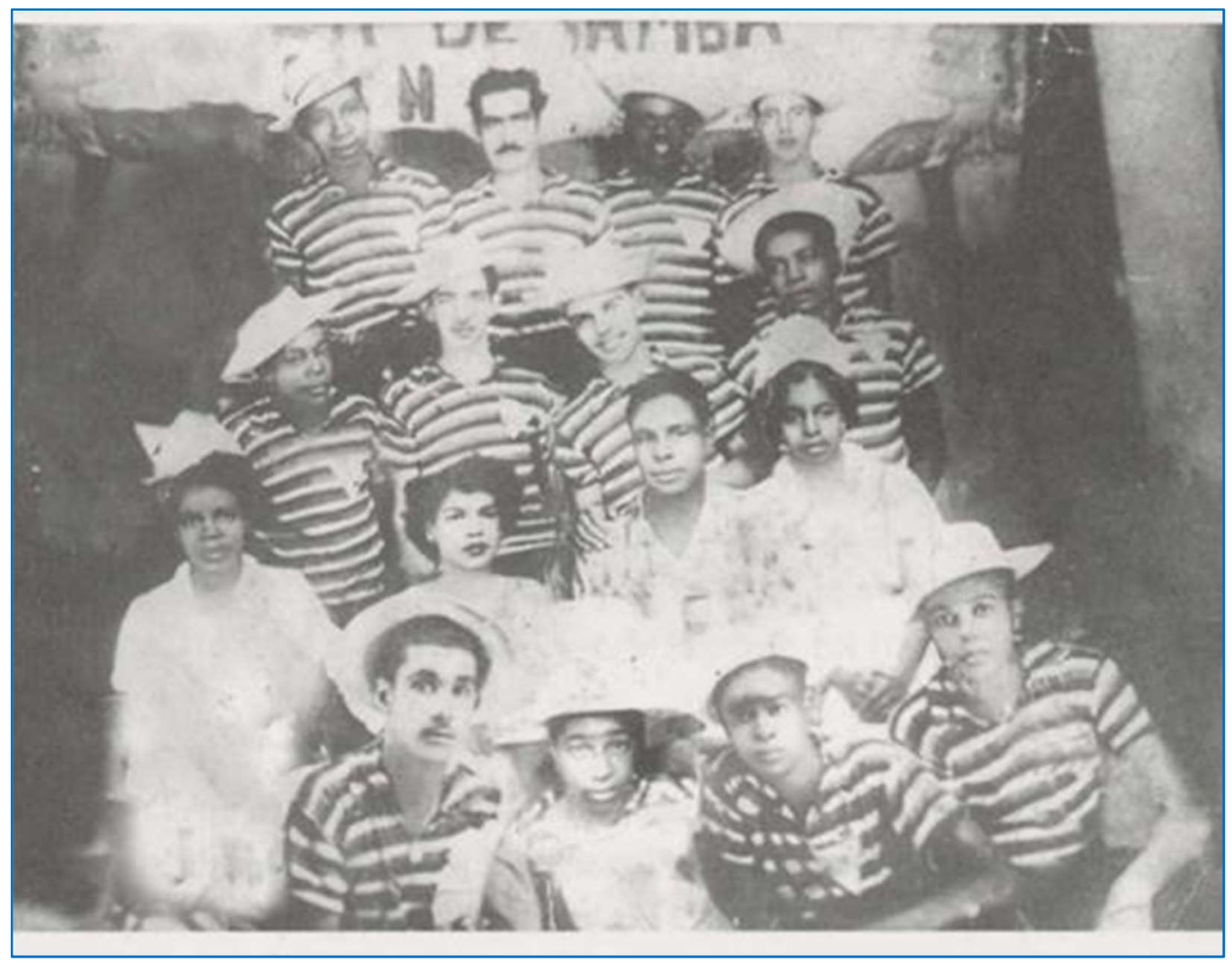

Figura 1 - Primeiro desfile da Escola de Samba Nenê da Vila Matilde, 1949.

Fonte: SILVA, BRAIA, 2000, p. 56.

\footnotetext{
${ }^{12}$ Propp, Vladimir. Comicidade e riso. São Paulo: Ática, 1992.
} 
Nos primeiros anos, informa Seu Nenê, o agrupamento cantava nos desfiles músicas de sucesso dos carnavais em curso e, à medida que se consolida, passa a introduzir os sambas-enredo para suas exibições (SILVA, BRAIA, 2000).

Entretanto, antes dessa discussão, convém demarcar as escolas de samba que já existiam na cidade, em 1949, mesmo sendo de pequeno porte, como observa Alberto Alves da Silva, Seu Nenê, um dos fundadores da escola de igual nome, a saber:

(Em 1949 existiam as seguintes escolas de samba:) [...] "21 de abril, do Brás; Lavapés; Cruzeiro do Sul; Unidos do Tatuapé (que faziam o carnaval da Rua Domingos de Oliveira até o Largo da Concórdia); no Centro, tinha a Brasil Moreno. Tinha a Primeira do Itaim, e na Penha tinha a Ases da Garoa, tinha a Acadêmicos de Tatuapé. Entre os bairros de Vila Formosa e Vila Isabel, tinham a Primeira e a Segunda de Vila Isabel. De Santo Amaro, tinham a Primeira e a Segunda de Santo Amaro. Tinha a Ipiruíbe da Mooca, que era só de branco... Tinha a Rosas Negras, que foi a vicecampeã no Quarto Centenário, a Som de Cristal e a Preto e Branco do Pires." (SILVA, BRAIA, 2000, p. 53-54)

Ainda mapeando as escolas de samba, no carnaval de 1955, tem-se notícias da existência de algumas agremiações na cidade, a exemplo da Escola de Samba Rosas Negras (mencionada anteriormente), do bairro da Liberdade, que desfilou na região central em homenagem ao jornal Correio Paulistano. No domingo de carnaval, o mesmo jornal noticia o desfile das escolas de samba Cruzeiro do Sul, Vila Vitória, Patriotas, Voz do Morro, Nenê da Vila Matilde, Coração de Bronze, Primeira de Santo Amaro e Garotos do Itaim. ${ }^{13}$ Da mesma forma, em 1959, o rol das escolas de samba apresentando-se no Parque Ibirapuera é significativo.

(Desfilaram nos três dias as seguintes escolas de samba e os cordões) [...] No domingo, sagraram-se vencedoras as escolas de samba Nenê da Vila Matilde (20 mil cruzeiros), Lavapés (10 mil) e Unidos do Morro de Vila Maria ( 5 mil). Prêmio extra de 5 mil cruzeiros foi conferido à escola de samba Unidos de Vila Peruche por ser a mais numerosa. Na segundafeira, foram classificadas as escolas de samba Unidos do Gavião (15 mil cruzeiros), Unidos da Casa Verde (10 mil), Jóqueis Unidos (6 mil) e mais Garotos do Ipiranga e Coração de Bronze (4 mil cada). No último dia, os prêmios foram levantados pelos seguintes cordões carnavalescos: Paulistano (20 mil cruzeiros) e Vai-Vai (15 mil cruzeiros). (Folha da Manhã, 12/02/1959, p. 4)

\footnotetext{
${ }^{13} \mathrm{~A}$ indicação dos nomes dos inscritos para os desfiles nem sempre ocorre como fez, nessa ocasião, o jornal Correio Paulistano. (CP, 15/02/1955, p. 8)
} 
No Gráfico 1, produzido segundo informações de fontes impressas (como os jornais diários e depoimento autobiográfico de Seu Nenê), é possível visualizar as escolas de samba existentes na capital de 1937 a 1967, ano anterior à oficialização do carnaval da cidade, seguindo o modelo carioca.

Gráfico 1 - Escolas de Samba de São Paulo - de 1937 a 1967

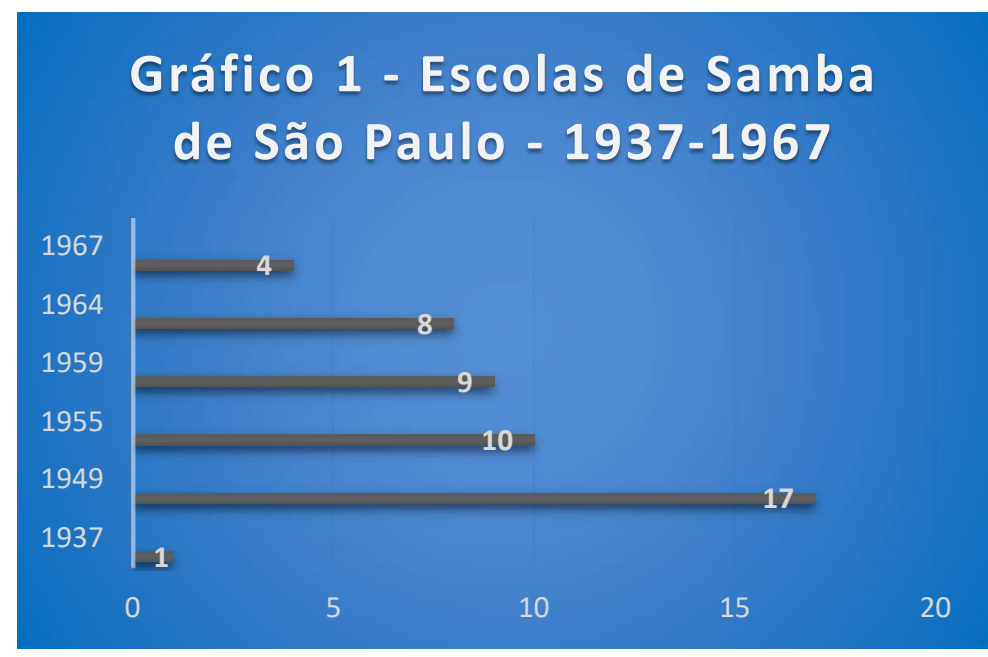

Fontes: Correio Paulistano, 15/02/1955, p. 8; Folha da Manhã, 12/02/1959, p. 4; Folha de S. Paulo (11/2/1964); SILVA, Alberto Alves, BRAIA, Ana. Memórias do Seu Nenê da Vila Matilde. São Paulo: Lemos Editorial, 2000).

Verifica-se, com base nos registros de Seu Nenê, que eram agremiações pequenas, cujo raio de exibição, na capital, era o bairro que as abrigava e acolhia, assim como aos seus integrantes. O Quadro 1, a seguir, traz informações coletadas sobre as escolas de samba existentes na capital paulista, expondo o nome da escola, o bairro e a data da primeira referência de sua exibição e não de sua fundação, exceto Lavapés, cujo ano de fundação e de primeira exibição coincidem. Em muitos casos, as informações da imprensa referem-se àquelas que foram premiadas nos desfiles oficiais, tanto em 1955 quanto em 1959, pois os jornais não trazem a lista de todas as escolas, somente daquelas que desfilaram ou ganharam algum prêmio.

Essas agremiações foram fundadas (tanto as escolas de samba, quanto os cordões) por jovens vinculados a uma unidade familiar e por amigos próximos que se reuniam para tocar os seus instrumentos ou fazer uma batucada, passo inicial para a formação tanto dos cordões quanto das escolas de samba. Essa foi a origem da Nenê, que agregou os batuqueiros que se reuniam no Largo do Peixe, o Vai-Vai no Bixiga ou os cordões da Barra Funda, cujos integrantes fundadores se reuniam para tocar os seus 
instrumentos na Alameda Glete, a exemplo de Camisa Verde e Branco, fundado por Dionísio Barboza, em 1914 (interrompido em 1939; retornou em 1953, pelas mãos de Inocêncio Tobias), e Campos Elyseos, em 1919.

Quadro 1 - Escolas de Samba - das origens (1937) até 1967

\begin{tabular}{|c|c|c|c|c|c|c|c|c|}
\hline Nome - Escola de samba & Bairro & 1937 & 1949 & 1955 & 1959 & 1964 & 1967 & Extinta \\
\hline Lavapés & Glicério & 1937 & 1949 & 1955 & 1959 & 1964 & 1967 & Ativa \\
\hline Nenê da Vila Matilde & Vila Matilde & & 1949 & 1955 & 1959 & 1964 & 1967 & Ativa \\
\hline Rosas Negras & Liberdade & & 1949 & 1955 & & & & \\
\hline Cruzeiro do Sul & & & 1949 & 1955 & & & & $\mathrm{~s} / \mathrm{i}$ \\
\hline 21 de Abril & Brás & & 1949 & & & & & $s / i$ \\
\hline Unidos do Tatuapé & Tatuapé & & 1949 & & & & & $s / i$ \\
\hline Brasil Moreno & Liberdade & & 1949 & & & & & \\
\hline Primeira do Itaim & Itaim & & 1949 & & & & & \\
\hline Ases da Garoa (cordão) & Penha & & 1949 & & & & & \\
\hline Acadêmicos de Tatuapé & Tatuapé & & 1949 & & & & & Ativa \\
\hline Primeira de Santo Amaro & $\begin{array}{l}\text { Santo } \\
\text { Amaro }\end{array}$ & & 1949 & 1955 & & & & \\
\hline Segunda de Santo Amaro & $\begin{array}{l}\text { Santo } \\
\text { Amaro }\end{array}$ & & 1949 & & & & & $\mathrm{~s} / \mathrm{i}$ \\
\hline Som de Cristal (cordão) & Centro & & 1949 & & & & & \\
\hline Preto e Branco do Pires & & & 1949 & & & & & $\mathrm{~s} / \mathrm{i}$ \\
\hline Primeira de Vila Isabel & Vila Isabel & & 1949 & & & & & $s / i$ \\
\hline Segunda de Vila Isabel & Vila Isabel & & 1949 & & & & & $\mathrm{~s} / \mathrm{i}$ \\
\hline Ipiruíbe (só de brancos) & Mooca & & 1949 & & & & & $s / i$ \\
\hline Patriotas & & & & 1955 & & & & $s / i$ \\
\hline Coração de Bronze & $\begin{array}{l}\text { Vila } \\
\text { Madalena }\end{array}$ & & & 1955 & 1959 & 1964 & & \\
\hline Garotos do Itaim & Itaim & & & 1955 & & & & \\
\hline Vila Vitória & & & & 1955 & & & & $\mathrm{~s} / \mathrm{i}$ \\
\hline $\begin{array}{l}\text { Unidos do Morro de Vila } \\
\text { Maria* }\end{array}$ & Vila Maria & & & & 1959 & 1964 & 1967 & Ativa \\
\hline Jóqueis Unidos & Pinheiros & & & & 1959 & & & \\
\hline Unidos do Galvão & & & & & 1959 & & & $\mathrm{~s} / \mathrm{i}$ \\
\hline Unidos da Casa Verde & Casa Verde & & & & 1959 & & & \\
\hline Garotos do Ipiranga** & Ipiranga & & & & 1959 & & & \\
\hline Unidos de Vila Peruche*** & $\begin{array}{l}\text { Parque } \\
\text { Peruche }\end{array}$ & & & & 1959 & 1964 & 1967 & Ativa \\
\hline Acadêmicos de Vila Jaguará & & & & & & 1964 & & $02 / 11 / 82$ \\
\hline Império do Samba & & & & & & 1964 & & $s / i$ \\
\hline Império do Cambuci & Cambuci & & & & & 1964 & & $\mathrm{~s} / \mathrm{i}$ \\
\hline
\end{tabular}

Fonte: Correio Paulistano, 15/02/1955, p. 8; Folha da Manhã, 12/02/1959, p. 4; Folha de S. Paulo, 11/2/1964. SILVA, Alberto Alves, BRAIA, Ana. Memórias do Seu Nenê da Vila Matilde. São Paulo: Lemos Editorial, $2000^{14}$.

${ }^{14}$ Camisa Verde e Branco foi um cordão fundado em 1914. Encerrou-se em 1939 e retornou em 1953. Tornouse escola de samba em 1971 ou 1973. Vai-Vai, fundado em 1930 como cordão, transformou-se em escola de samba em 1971. Somente a data de 1937 é de criação da escola Lavapés. As demais datas são referências 
Assim, agregar outros integrantes a esse núcleo inicial, no decurso dos anos, permitiu que algumas dessas agremiações chegassem a 1967 com os mesmos dirigentes ou com os seus continuadores, como acontece com as escolas de samba Lavapés, Nenê da Vila Matilde, Acadêmicos de Tatuapé, Unidos do Morro de Vila Maria, Unidos de Vila Peruche e os cordões Camisa Verde e Branco, Cordão Futebolístico Carnavalesco Vai-Vai e o Cordão Carnavalesco Campos Elyseos, conforme o Quadro 2, indicado a seguir.

Quadro 2 - Dirigentes das escolas de samba/cordões em 1967

\begin{tabular}{|c|c|c|}
\hline Escola de samba/Cordão & Dirigente & Bairro \\
\hline Lavapés (Criada em 1937) & $\begin{array}{l}\text { Diolinda Madre (Madrinha Eunice - } \\
\text { fundadora) }\end{array}$ & Glicério \\
\hline $\begin{array}{l}\text { Nenê da Vila Matilde } \\
\text { (Criada em 1949) }\end{array}$ & $\begin{array}{l}\text { Alberto Alves da Silva (Seu Nenê - } \\
\text { fundador) }\end{array}$ & $\begin{array}{l}\text { Vila Matilde } \\
\text { (Zona Leste) }\end{array}$ \\
\hline $\begin{array}{l}\text { Unidos de Vila Peruche } \\
\text { (Criada em 04/01/1956) }\end{array}$ & Carlos Alberto Caetano (Carlão) & Parque Peruche \\
\hline Unidos do Morro de Vila Maria & Xangô & Vila Maria \\
\hline $\begin{array}{l}\text { Morro da Casa Verde } \\
\text { (Criada em 06/04/1962 - Dissidência da } \\
\text { Unidos do Morro da Casa Verde) }\end{array}$ & Zezinho Nazareth & Casa Verde \\
\hline $\begin{array}{l}\text { Camisa Verde e Branco (Cordão - } \\
\text { 1914/escola de samba - 1953) }\end{array}$ & $\begin{array}{l}\text { Dionísio Barboza (fundador) } \\
\text { Inocêncio Tobias (continuador) }\end{array}$ & Barra Funda \\
\hline Vai-Vai (cordão: 1930-1971) & $\begin{array}{l}\text { Sebastião Eduardo Amaral (Pé } \\
\text { Rachado - continuador) }\end{array}$ & Bixiga \\
\hline $\begin{array}{l}\text { Campos Elyseos (Cordão - criado em } \\
\text { 1919) }\end{array}$ & Dona Cecília (continuadora) & Barra Funda \\
\hline
\end{tabular}

Fonte: SILVA, Alberto Alves, BRAIA, Ana. Memórias do Seu Nenê da Vila Matilde. São Paulo: Lemos Editorial, 2000.

De acordo com Silva (2008) e Amaral (1981), alguns desses protagonistas carnavalescos relembram os "cordões" e escolas que se tornaram referência, pela tradição e qualidade de seus músicos e ritmistas e, por isso, consagraram-se nos carnavais

de desfiles. A Unidos da Casa Verde teve uma dissidência em 1962, surgindo a Escola de Samba Morro da Casa Verde, dirigida pelo Sr. Zezinho de Nazareth. Após sua morte, sucedeu-o Laurinete Nazaré da Silva Campos (Guga), sua filha.

* Unidos de Vila Maria foi criada em 10/01/1954.

**Garotos do Ipiranga foi substituída por Acadêmicos do Ipiranga em 30/09/1967.

*** A Escola de Samba Unidos de Vila Peruche foi criada em 4 de janeiro de 1956.

s/i (sem identificação). 
da cidade ${ }^{15}$, tornando-se matriz de muitas agremiações de igual natureza. Nesse sentido, essas nomenclaturas são vistas por tais dirigentes como mera formalidade, pois as diferenças são pautadas pelo samba/ritmo e a qualidade dos músicos e instrumentistas que integram sua bateria, como observam Alberto Alves da Silva (Seu Nenê) e Sebastião Eduardo Amaral (Pé Rachado, do Vai-Vai) (SILVA, 2012), embora a estrutura de um cordão fosse bastante diferente de uma Escola, como lembra Sebastião Amaral:

No cordão, no Abre alas eram os clarins. Até um clarim era importante. Mas até quatro era uma beleza.

Tinha um corpo de balizas. Eram grandes - cinco ou seis. Tinham homens e mulheres balizas. No (cordão) Vai-Vai tinham três.

Vinham as filas.

E depois a "corte". Era uma corte completa. Não era muito completa. Tinha o Rei e a rainha.

Depois da corte tinha Alegoria, que era o explicativo do enredo. A $1^{\mathrm{a}}$ Alegoria foi a chegada da corte no Brasil.

Depois vinha a bateria (12). Era só caixa, bumbo, cuíca. Quando saiu em 1966 tinham 165. (MIS/SP- AMARAL - Entrevista dada em 02/10/1981)

Diferentemente dessa experiência, a Escola de samba "Nenê", por exemplo, já começou bastante afinada, como afirma o relato de Seu Nenê, uma vez que tinham "uma boa percussão, porque a maioria era músico, e isso foi uma coisa que logo destacou a escola. Tínhamos malacacheta, tamborim, chocalho, agogô, surdo. Desde o primeiro momento, tivemos uma pegada de escola de samba" (SILVA, BRAIA, 2000, p. 56).

Os espaços, os temas e as encenações de "Nenê da Vila Matilde": os significados possíveis

Assim, a cartografia, mesmo lacunar, dessas escolas permite que se considere sua espacialidade e as possíveis exibições de suas performances nos diversos ambientes da cidade, oficiais ou não, a exemplo dos bairros Vila Esperança, na Zona Leste; Largo

\footnotetext{
15 Diz Seu Nenê que, ao começarem em 1949 com a Nenê da Vila Matilde, já existiam, em São Paulo, várias escolas, como já exposto no corpo do texto (SILVA, BRAIA, 2000, p. 53-54). Também existiam os antigos cordões, que foram as bases de muitas escolas de samba como: Camisa Verde e Branco, criado em 1914, interrompido em 1939 e com retorno em 1953. Vai-Vai era um cordão, criado em 1930, e somente se tornou Escola de Samba em 1971. Sr. Zezinho e Sebastião Amaral também realçam a qualidade de alguns músicos e ritmistas desses cordões em seus depoimentos gravados e integrantes do acervo do MIS Museu da Imagem e do Som de São Paulo (SILVA, 2008; 2012).
} 
Lapeano, na Lapa; Liberdade; Tatuapé; Santo Amaro ${ }^{16}$. Também participaram dos carnavais da Avenida São João e dos Parques Dom Pedro II e Parque do Ibirapuera, entre outros, identificados nos registros da imprensa como os palcos dos desfiles oficiais das escolas de samba. Por exemplo, essas agremiações desfilaram no Ibirapuera de 1955 a 1959, no carnaval oficial da cidade, conforme aponta o Gráfico 2, a seguir ${ }^{17}$. Esses registros são apenas indicativos, pois as informações da imprensa são genéricas, como pode-se observar em relação aos eventos de $1958^{18}$. Ou, então, centradas naquelas que foram vencedoras, às vezes, citando apenas o primeiro lugar, como já foi explicitado anteriormente.

Gráfico 2 - Desfiles no Ibirapuera das Escolas de Samba - 1955-1959

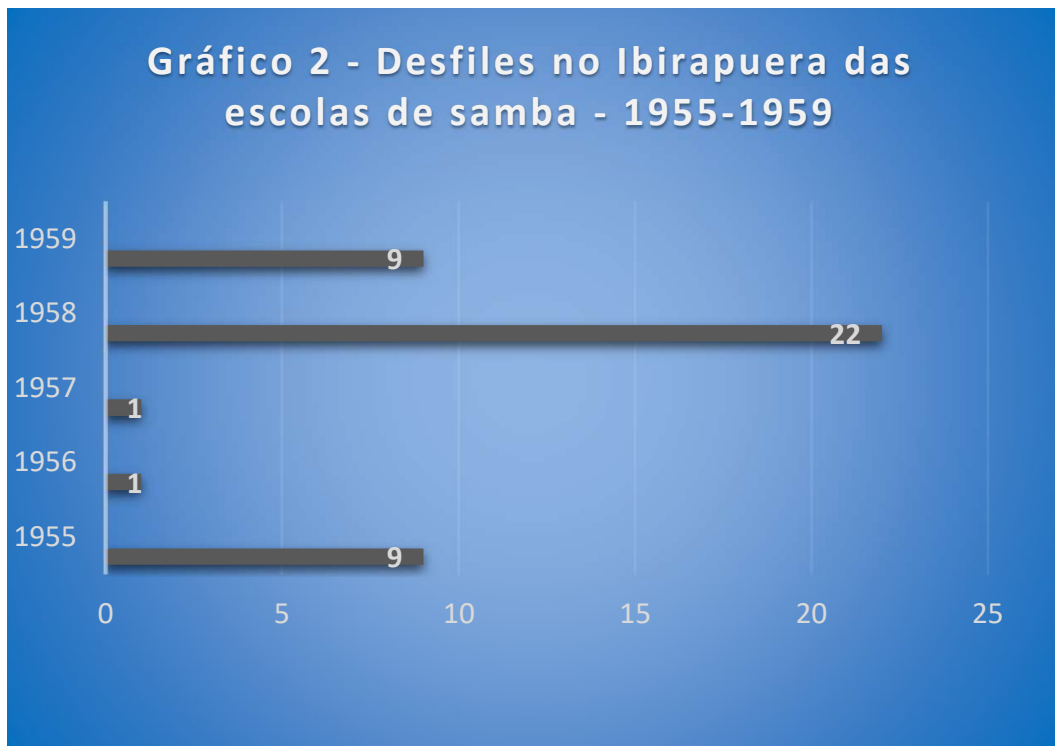

Fonte: Correio Paulistano (15/02/1955, p. 8; 05/03/1957, p. 1); Folha da Manhã (16/02/1956; 20/02/1958; 12/02/1959); O Estado de S. Paulo [23/1/1958]. Os jornais destacam as Escolas que foram premiadas.

${ }^{16}$ A cartografia do samba na cidade de São Paulo já foi mapeada pelos pesquisadores, a exemplo de Olga von Simson (2007), leda Marques Britto (1986) e Wilson de Moraes (1978), em momentos distintos de sua trajetória. Nesse trajeto, destacou-se a Barra Funda como matriz desses agrupamentos, espalhandose pelos bairros onde se localizava a comunidade negra em tempos distintos. A pesquisa de Alessandro Dozena, sobre As territorialidades do samba na cidade de São Paulo (2009), recupera demarcações plenamente consolidadas ao privilegiar duas agremiações: Vai-Vai (surgida como cordão em 1930) e Peruche (escola de samba criada em 1956), que tiveram percursos distintos nesse processo.

17 Nesses palcos, eram também exibidas as encenações dos cordões, alguns já consagrados na memória dos carnavais da cidade, mesmo porque a origem de alguns deles remontava à década de 1920, como já assinalado anteriormente. No Gráfico 2, porém, apenas as escolas de samba foram especificadas, inclusive o ano de 1958, que registra vinte e duas agremiações, ao passo que o Quadro 1 não assinala nenhuma informação sobre o assunto. Isso se deve à ausência de registros detalhados da imprensa sobre quais seriam essas escolas.

${ }^{18}$ Por não constar o nome das escolas, essa informação não fez parte do Gráfico 1. 
O mapeamento, acima, sugere indagações sobre os assuntos apresentados por essas agremiações aos demais pândegos. Os registros são raros, exigindo ampla pesquisa. No caso da Escola de Samba Nenê da Vila Matilde, essa recuperação beneficiase dos relatos de seu Nenê (SILVA, BRAIA, 2000), que informa que a Escola usou, inicialmente, letras de músicas que faziam sucesso nas rádios como mote para os seus desfiles de 1950 a 1953. Seu Nenê relembra algumas delas: Normalista (1950)19, Amor de Madalena (1951), de Blecaute, Lata d'água (1952) e Joga a Chave (1953) $)^{21}$. Nos anos seguintes, a Escola, inspirando-se nos desfiles das escolas de samba do Rio de Janeiro ${ }^{22}$, apresenta temas que se deslocam ao universo sociopolítico do passado do grupo, a exemplo de 1954, com Zumbi dos Palmares, e, também, questões relativas ao país e ao estado de São Paulo.

As motivações para essas mudanças de foco podem ser pensadas além do exemplo carioca? Não seria esse o espaço adequado para a busca de inversão da ordem,

${ }^{19}$ A letra de Normalista (Nelson Gonçalves) permite encenações diversas, embora traga uma perspectiva romântica que se aproxima aos amores de carnaval, sempre adiados, conforme defende a versão romântica de Pierrô. A letra é a seguinte: "Vestida de azul e branco / Trazendo um sorriso franco / No rostinho encantador / Minha linda normalista / Rapidamente conquista / Meu coração sem amor / Eu que trazia fechado / Dentro do peito guardado / Meu coração sofredor / Estou bastante inclinado / A entregálo ao cuidado / Daquele brotinho em flor / Mas a normalista linda / Não pode casar ainda / Só depois que se formar... / Eu estou apaixonado / O pai da moça é zangado / E o remédio é esperar".

${ }^{20} \mathrm{O}$ tema volta-se às questões vivenciadas pela comunidade negra, em seu dia a dia, retratada na letra: "Lata d'água na cabeça / Lá vai Maria / Lá vai Maria / Sobe o morro e não se cansa / Pela mão leva a criança / Lá vai Maria / Maria / Lava roupa lá no alto / Lutando / Pelo pão de cada dia / Sonhando / Com a vida do asfalto / Que acaba / Onde o morro principia / Lata d'água na cabeça...” (Compositor: Luis Antonio - Jota Jr.).

${ }^{21} \mathrm{~A}$ letra aborda a relação do boêmio com sua amada: "Não perturbo mais teu sono / Chego à meia noite, sim / Ou então a qualquer hora / Joga a chave, meu bem / Aqui fora tá ruim demais / Cheguei tarde, perturbei teu sono / Amanhã eu não perturbo mais / Joga a chave, meu bem / Aqui fora tá ruim demais / Cheguei tarde, perturbei teu sono / Amanhã eu não perturbo mais / Faço um furo na porta / Amarro um cordão no trinco / Pra abrir pro lado de fora / Não perturbo mais teu sono / Chego à meia-noite, sim / Ou então a qualquer hora / Joga a chave, meu bem / Aqui fora tá ruim demais / Cheguei tarde, perturbei teu sono / Amanhã eu não perturbo mais" (Compositores: Adoniran Barbosa/ Oswaldo Franca). Link: $<$ http://www.vagalume.com.br/adoniran-barbosa/joga-a-chave.html\#ixzzzgorBZI4u >.

${ }^{22}$ A inspiração refere-se ao "samba-enredo" enquanto modalidade de desfile, cuja estrutura de exibição apoia-se no assunto escolhido, com música atinente à proposta temática. Cabe lembrar que o temário afro faz parte das origens e vivências da comunidade negra e estará presente tanto nos desfiles das agremiações negras do Rio de Janeiro, quanto nas de São Paulo e, provavelmente, nas agremiações de outras regiões. Esse temário aparece em 1948 e, de forma contundente, em 1949, no Rio de Janeiro, e também nos anos seguintes. (Essas informaç̃̃es sobre o Rio de Janeiro foram sistematizadas por Danilo Alves Bezerra, para sua tese de doutorado, em 2015, a partir do endereço: $<w w w$.galeriadosamba.com.br $>$. Portanto, o acesso de Bezerra ao arquivo "Galeria do samba" ocorreu em: 14/09/2015). 
processo de carnavalização, revertendo os sinais, conforme analisa Bakhtin (1987), para outra experiência? E os sambas-enredo, peças importantes nessa teatralização, conseguiram extravasar para a sociedade, nesses desfiles, os sentimentos do grupo sobre o seu passado?

Rastrear esses temas pode esclarecer dimensões do assunto, mesmo porque alguns dos motes referem-se ao universo afro, projetando-se aqueles referentes à problemática da escravidão negra, analisada em diferentes momentos: primeiramente, expresso na homenagem a Zumbi dos Palmares ${ }^{23}$, depois em temas correlatos. Porém, suas exibições ocorreram na conjuntura anterior ao golpe militar de 1964, período que se caracteriza por intensa efervescência política. A hipótese é que essa conjuntura, mesmo subjetivamente, acabe por imprimir sua marca nessas escolhas, pois a intenção dos carnavalescos é repensar o passado escravo, de dor e sofrimento dos descendentes afrobrasileiros, a julgar pelas questões dessa natureza trazidas a eventos dedicados à alegria, como o carnaval.

O resultado do levantamento sobre as performances de Nenê da Vila Matilde, entre os anos de 1950 a 1967, indica temas relacionados a letras de música em voga, temas ligados às questões do grupo e outros assuntos de âmbito nacional, além de um vínculo com o passado paulista ao tratar o tema do bandeirante, como evidenciam o Quadro 3, a seguir, e o Gráfico 3, mais adiante.

Nos registros de seu Nenê, somente em 1956 é que a Escola desfila o seu primeiro samba-enredo. Essa modalidade de exibição, segundo Monique Augras (1998), citando Tinhorão, é a adequação do samba à temática do desfile. Na interpretação da autora, ele teria aparecido nos desfiles carnavalescos do Rio de Janeiro, em 1933, com algumas

\footnotetext{
${ }^{23}$ Os desfiles das escolas de samba em São Paulo, em 1954, são feitos sob outras expectativas considerando que se trata do IV Centenário da cidade de São Paulo, marcado por muitas homenagens sobre os feitos paulistas. Os negros estavam excluídos das comemorações, fato que desagradou bastante à comunidade negra, considerando que foi o seu trabalho escravo que engrandeceu o Estado, ao longo dos séculos XVIII e XIX. (LOPES, 2007)
} 
um enredo. O tema era "Asas para o Brasil” e homenageava Santos Dumont. A autora explica o surgimento do samba-enredo como uma decorrência do enquadramento oficial dos desfiles.

No caso paulista, a experiência temática ocorreu na exibição de temas sociais ou associados à identidade de São Paulo e do país. A Nenê trouxe, inicialmente, a leitura de Casa Grande e Senzala para a avenida, assunto que será abordado posteriormente.

Os motes dos demais desfiles carnavalescos estão sintetizados no Quadro 3, a seguir, que traz informações detalhadas das exibições feitas pela Escola de Samba Nenê da Vila Matilde.

Quadro 3 - Temas dos desfiles da Escola de Samba Nenê da Vila Matilde (1954-1967)

\begin{tabular}{|c|c|c|c|c|}
\hline Ano & Nome & Sambas-enredo & Carnavalescos/sambistas & Referência \\
\hline 1954 & $\begin{array}{l}\text { Nenê da } \\
\text { Vila } \\
\text { Matilde }\end{array}$ & $\begin{array}{l}\text { Zumbi dos Palmares } \\
\text { (tema) }\end{array}$ & $\begin{array}{l}\text { Alvaro Pedro Rosa } \\
\text { (Paulistinha) e Mário } \\
\text { Protestato (Popó) }\end{array}$ & $\begin{array}{l}\text { Olga von } \\
\text { Simson (fotos) }\end{array}$ \\
\hline 1955 & & Tabuleiro da Baiana & $\begin{array}{l}\text { Álvaro Pedro Rosa } \\
\text { (Paulistinha) e Mário } \\
\text { Protestato (Popó) }\end{array}$ & \\
\hline 1956 & & $\begin{array}{l}\text { Casa Grande e Senzala ( } 1^{\circ} \\
\text { samba-enredo) }\end{array}$ & $\begin{array}{l}\text { Álvaro Pedro Rosa } \\
\text { (Paulistinha) e Mário } \\
\text { Protestato (Popó) }\end{array}$ & Seu Nenê \\
\hline 1957 & & Lei Áurea & Leônidas & Seu Nenê \\
\hline 1958 & & O grito do Ipiranga & $\begin{array}{l}\text { Antonio Pedro Alves de } \\
\text { Almeida (Tóquio) e Álvaro } \\
\text { Pedro Rosa (Paulistinha) }\end{array}$ & Seu Nenê \\
\hline 1959 & & Chica da Silva & $\begin{array}{l}\text { Álvaro Pedro Rosa } \\
\text { (Paulistinha) e Mário } \\
\text { Protestato (Popó) }\end{array}$ & Seu Nenê \\
\hline 1960 & & Despertar de um Gigante & Mário Protestato (Popó) & Seu Nenê \\
\hline 1961 & & A Marquesa de Santos & $\begin{array}{l}\text { Antonio Pedro Alves de } \\
\text { Almeida (Tóquio) e Álvaro } \\
\text { Pedro Rosa (Paulistinha) }\end{array}$ & $\begin{array}{l}\text { Olga von } \\
\text { Simson (fotos) }\end{array}$ \\
\hline 1962 & & A escrava Isaura & $\begin{array}{l}\text { Antonio Pedro Alves de } \\
\text { Almeida (Tóquio) e Álvaro } \\
\text { Pedro Rosa (Paulistinha) }\end{array}$ & $\begin{array}{l}\text { Olga von } \\
\text { Simson (fotos) }\end{array}$ \\
\hline
\end{tabular}




\begin{tabular}{|c|c|c|c|}
\hline 1963 & Enaltecendo uma raça & $\begin{array}{l}\text { Antonio Pedro Alves de } \\
\text { Almeida (Tóquio) e Álvaro } \\
\text { Pedro Rosa (Paulistinha) }\end{array}$ & $\begin{array}{l}\text { Olga von } \\
\text { Simson (fotos) }\end{array}$ \\
\hline 1964 & $\begin{array}{l}\text { Paes Leme, o } \\
\text { Bandeirante (tema) }\end{array}$ & $\begin{array}{l}\text { Antonio Pedro Alves de } \\
\text { Almeida (Tóquio) e Álvaro } \\
\text { Pedro Rosa (Paulistinha) }\end{array}$ & $\begin{array}{l}\text { Olga von } \\
\text { Simson (fotos) }\end{array}$ \\
\hline 1965 & [Carlos Gomes]* $^{*}$ & $\begin{array}{l}\text { Antonio Pedro Alves de } \\
\text { Almeida (Tóquio) e Álvaro } \\
\text { Pedro Rosa (Paulistinha) }\end{array}$ & Seu Nenê \\
\hline 1966 & José do Patrocínio & & \\
\hline 1967 & O Tronco do Ipê (tema) & & $\begin{array}{l}\text { Olga von } \\
\text { Simson (fotos) }\end{array}$ \\
\hline
\end{tabular}

Fontes: SILVA, Alberto Alves, BRAIA, Ana. Memórias do Seu Nenê da Vila Matilde. São Paulo: Lemos Editorial, 2000); SIMSON, Olga Rodrigues de Moraes von. Carnaval em branco e negro. São Paulo: EDUSP, 2007, p.314-336.

* Seu Nenê cita o samba-enredo Carlos Gomes, de autoria de Tóquio, mas não fala o ano (SILVA, BRAIA, 2000, p. 45). https://pt.wikipedia.org/wiki/Nen\%C3\%AA_de_Vila_Matilde. Acesso em 19/9/2015.

A origem dessa mudança de estrutura dos desfiles é atribuída (conforme depoimento de Seu Nenê) ao contato com o mundo do samba carioca, que teria provocado inquietações sobre as possibilidades de outros arranjos para os desfiles carnavalescos. Essas novas ideias foram partilhadas com outros integrantes da diretoria da Escola, resultando na introdução do uso de alegorias e samba-enredo, em vez de temas vinculados a letras de música em voga, recorrentemente empregados pelas agremiações. Essa sistemática, contudo, não foi acompanhada pelas demais escolas, como mostra o Quadro 4, a seguir, no qual é possível observar que apenas Unidos de Vila Peruche propõe samba-enredo, situação que se altera de 1968 em diante.

Quadro 4 - Temas dos desfiles da Escola de Samba de São Paulo (1954-1967)

\begin{tabular}{|l|l|l|}
\hline Escolas & Ano & Temas dos sambas-enredo \\
\hline Nenê da Vila Matilde & 1954 a 1967 & Samba-enredo em todos os anos \\
\hline Lavapés & 1955 a 1967 & Não tem samba-enredo \\
\hline Unidos da Vila Peruche & 1965 & IV Centenário do Rio de Janeiro \\
& 1966 & Homenagem a Carlos Gomes \\
& 1967 & Exaltação a São Paulo \\
\hline
\end{tabular}

Fontes: SILVA, Alberto Alves, BRAIA, Ana. Memórias do Seu Nenê da Vila Matilde. São Paulo: Lemos Editorial, 2000; SIMSON, Olga Rodrigues de Moraes von. Carnaval em branco e negro. São Paulo. EDUSP, 2007, p. 314-336. https://pt.wikipedia.org/wiki/Nen\%C3\%AA_de_Vila_Matilde. Acesso em 19/9/2015. 
No caso paulista, portanto, o uso do samba-enredo pelas escolas, antes de 1968, não era resultante do processo de "institucionalização dos desfiles", que sofria pressão do julgamento das comissões oficiais - que existiam em São Paulo desde a gestão do Prefeito Fábio Prado, na década de 1930 (SILVA, 2008) -, considerando que a oficialização do carnaval paulistano, de fato, somente ocorrerá em 1968.

O Gráfico 3, a seguir, sistematiza essas informações, agrupando-as por temas. Alguns elementos chamam a atenção no carnaval paulistano das escolas de samba, pois buscavam inserir "novidades" que se consolidam no carnaval carioca. Presencia-se o uso de alegorias e dos sambas-enredo, com destaque para os temas voltados ao universo afro.

Gráfico 3 - Temas dos desfiles da Escola de Samba Nenê da Vila Matilde - 1950 a 1967

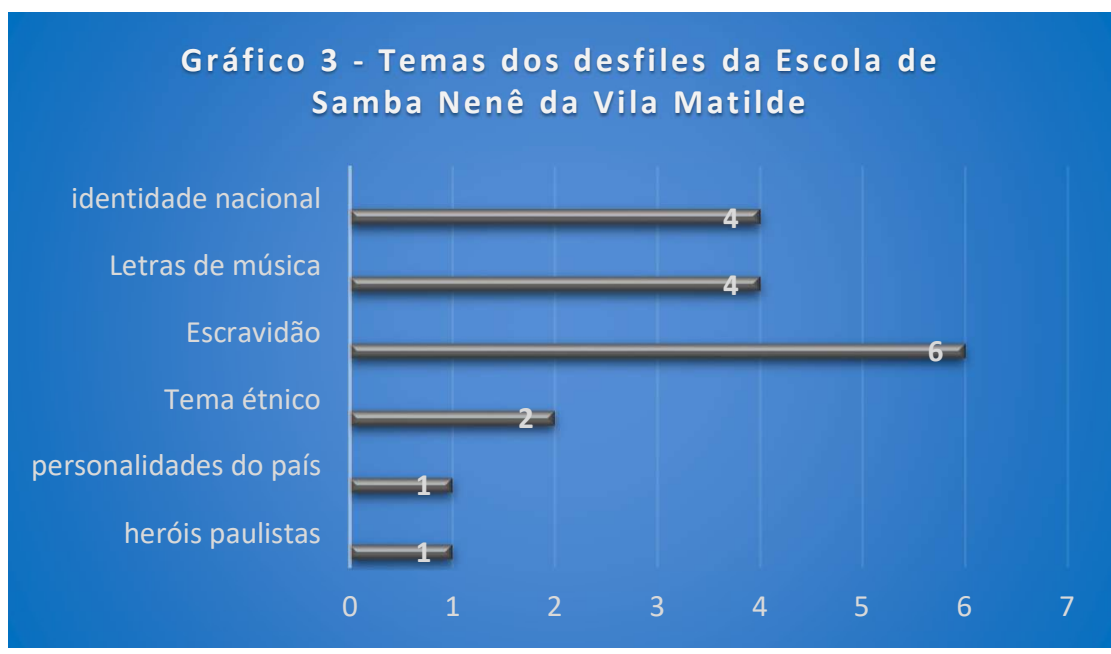

Fonte: SILVA, Alberto Alves, BRAIA, Ana. Memórias do Seu Nenê da Vila Matilde. São Paulo: Lemos Editorial, 2000); SIMSON, Olga Rodrigues de Moraes von. Carnaval em branco e negro. São Paulo: EDUSP, 2007, p.314-336.

Prosseguindo o exame do Quadro 3 e do Gráfico 3, nota-se que, embora não haja descrição da estrutura dos desfiles, os temas percorrem o prolongado cativeiro e as agruras, por vários séculos, provocadas pela involuntária "diáspora" negra e assuntos voltados à identidade nacional. O primeiro bloco relativo ao universo afro é exibido na avenida, em 1954, na homenagem ao principal líder negro da luta contra a escravidão, como já mencionado anteriormente. 


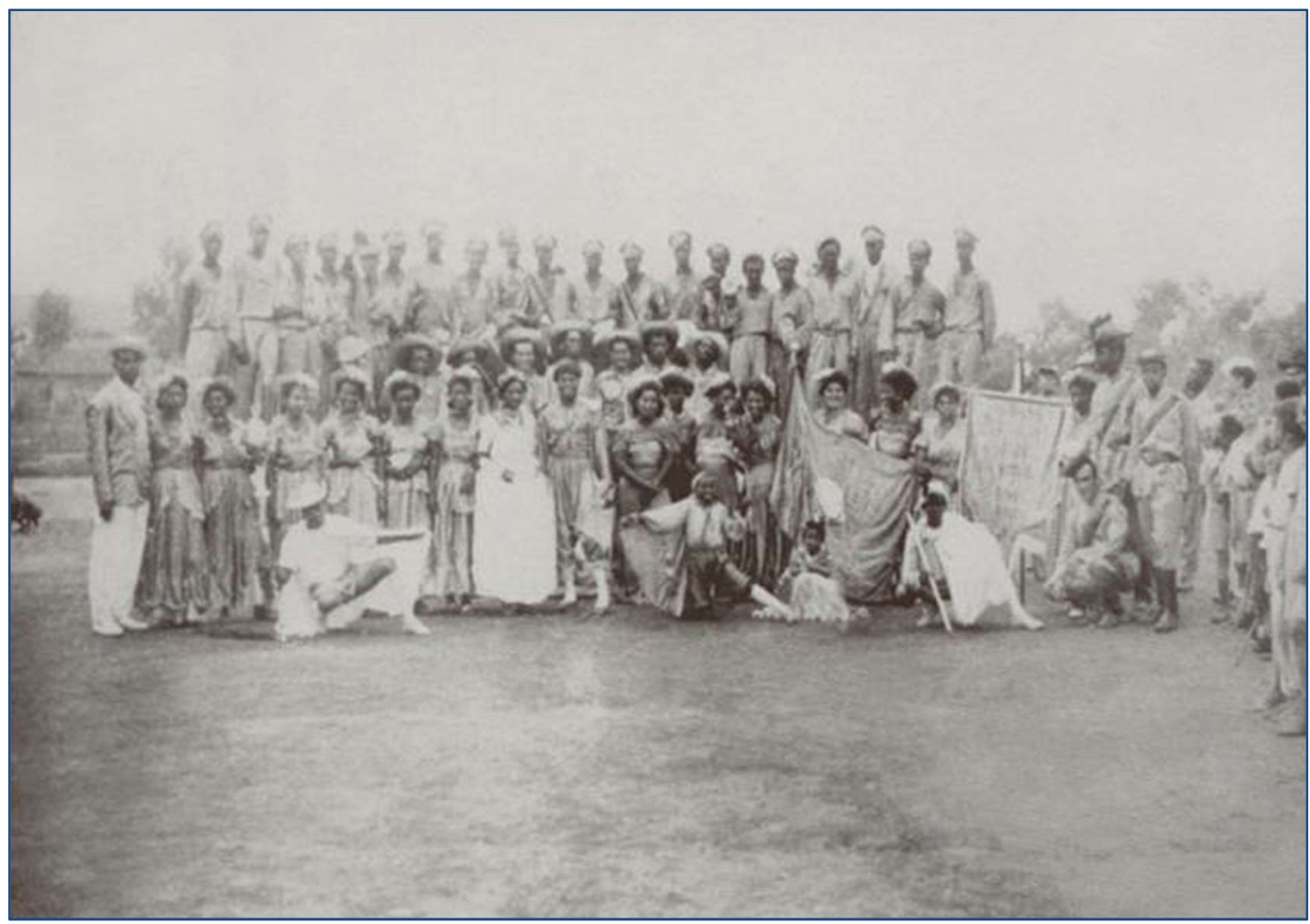

Figura 2 - Zumbi dos Palmares - 1954. Desfile da Escola de Samba Nenê da Vila Matilde (1954). Fonte: SIMSON, 2007, p.317.

Zumbi, o líder negro rebelde que integrou o quilombo dos Palmares e, de lá, liderou a luta contra a escravidão 24 , enfrentando as tropas do império colonial português por várias décadas, ganha a avenida para orgulho de sua comunidade. O tema, de forma alegórica, relembra a situação dos negros cativos de outrora, bem como participa dos embates de memória entre os diversos grupos de então, que reivindicam ser os responsáveis pela riqueza do estado de São Paulo, em seu IV Centenário. ${ }^{25}$ O grupo

24 Do quilombo de Palmares, localizado na Província de Pernambuco, Zumbi dos Palmares liderou a luta contra a escravidão, de 1675 a 20 de novembro de 1695, quando foi capturado e morto pelas tropas bandeirantes. (GOMES, 2011)

25 Pelo caráter simbólico de que se revestem, vale lembrar que os festejos carnavalescos de 1954, ano do IV Centenário da Cidade de São Paulo, deveriam ser distintivos em relação aos anos anteriores. No calendário desses festejos, em relação à comunidade negra, a programação do evento contemplava apenas os desfiles de escolas de samba, o que não era somente o esperado pelas lideranças negras que desejavam marcar sua presença nas celebrações do IV Centenário da Cidade e na memória oficial, como esclarece Maria Aparecida de Oliveira Lopes (2007) de forma incisiva, de modo que houvesse o reconhecimento de sua participação na construção do apogeu do Estado de São Paulo. Para tanto, propunham a criação de um museu da escravidão contendo, além da contribuição cultural do grupo, os diversos artefatos de tortura usados para submetê-los no prolongado cativeiro. A proposta não foi aprovada pelas elites que coordenavam as ditas atividades de celebração dos feitos paulistas. $O$ resultado das disputas pela memória da grandeza do Estado resultou numa homenagem à comunidade negra por meio de um monumento dedicado à mãe preta, figura mítica que traz no colo uma criança 
enredo) e sua superação com a Lei Áurea, que é o momento de ruptura dessa situação de escravização dos africanos e seus descendentes. Porém, novamente o tema é apresentado em Chica da Silva e, posteriormente, em A escrava Isaura (Figura 4), deixando antever que não se trata apenas de encenação ritualizada, mas uma forma de, meio século após a abolição, não apagar da memória das novas gerações a experiência de dor e violência sofrida pelos seus pais, avós e antepassados.

Assim, recuperando essa trajetória, tem-se, em 1956, o primeiro samba-enredo apresentado pela Nenê da Vila Matilde. Embora as explicações de seu principal protagonista, Seu Nenê, sobre a escolha de assuntos gerais ou voltados à questão afro apareçam naturalizadas, os sentidos vão além do desejo de "inovar" os desfiles. A ideia do tema Casa Grande e Senzala, diz Seu Nenê, foi uma sugestão de Mario Protestano dos Santos (Popó) e Dr. Lucrécio, não obstante o desenvolvimento do assunto tenha sido decisão coletiva: dele, do Popó, da mulher, Maria Tereza, Antonio Pedro Alves de Almeida (Tóquio), de Dr. Lucrécio e de Nicolau. A autoria do samba-enredo ${ }^{26}$, cuja letra expomos a seguir, coube a Álvaro Pedro Rosa (Paulistinha) e Popó (Mário Protestano dos Santos), jornalista de O Dia:

\author{
Samba-enredo Casa Grande e Senzala (1956) - (SILVA, BRAIA, 2000, p. 16). \\ Aruanda ficou, o mar separou \\ Senhor! Meu Senhor! \\ Nego tudo deixou \\ É banzo que nego tem \\ É banzo que nego tem \\ Na casa grande tudo é alegria \\ Na casa grande tudo é festança \\ Na senzala nego chora \\ Chora que nem criança \\ É banzo que nego tem \\ É banzo que nego tem
}

branca, representação que busca apaziguar as diferenças raciais e neutralizar a triste lembrança do cativeiro - assim pensavam as elites (e até algumas lideranças negras daquele momento).

${ }^{26}$ Este foi o único samba-enredo cuja letra foi registrada por Seu Nenê em suas memórias. 
O conteúdo do samba-enredo que, por si só, indica uma perspectiva crítica sobre o passado de escravização do grupo, não é o que traduz a letra, que aborda a escravidão como um infortúnio acidental vivido pelo negro que foi separado de sua África querida. Confinado na senzala, lamenta sua falta de sorte sendo consumido pela tristeza, choro e desamparo. O tom conformista, que é apenas uma das facetas da escravidão, não abarca a trajetória vivenciada pelos negros, que amargaram um prolongado cativeiro no país, sofrendo todo tipo de violência. Sabe-se, pela bibliografia especializada ${ }^{27}$, que a trajetória cativa do grupo vai além das lágrimas, e está marcada por diversas formas de enfrentamento ao sistema escravocrata: fuga, assassinato de seus algozes, resistência armada, rebeliões, entre outras.

Não há descrição sobre o planejamento e execução do enredo para o desfile, tais como a decisão da indumentária e demais apetrechos complementares para sua exibição. A foto, em preto e branco, tirada após o desfile da escola, no quintal da casa do pai de Seu Nenê - a escola ainda não tinha sede —, permite ver como o tema foi mostrado ao público, bem como a alegria de seus componentes ao exibir o troféu recebido.

Nessa foto, os homens e mulheres vestem fantasias diferenciadas, na busca de execução do enredo. Quantos aos homens, alguns usam chapéus, outros turbantes ou nenhum adereço na cabeça. Já as mulheres trajam roupas igualmente diferenciadas, algumas sem muitos enfeites, a não ser na cabeça, que aparece adornada com chapéus (as sinhazinhas), lenços e adereços não identificados. Há elementos na foto que sugerem que alguns trajes são de cor branca, mas havia uma parte da indumentária de algumas mulheres, provavelmente as escravas, que tinham uma espécie de avental de outra cor por cima de parte da saia. Também não há indicação de adereços. Olga von Simson esclarece a importância da indumentária, tanto masculina quanto feminina, para

\footnotetext{
27 A bibliografia é bastante extensa sobre esta questão. Lembro-me, entre tantos, de Onda negra, medo branco. O negro no imaginário das elites. Século XIX, de Célia Maria Marinho de Azevedo, publicado em 1987, traz os embates sobre a solução escrava entre os antagonistas, divididos sobre o assunto e a ação dos negros nesse processo, acelerando o compasso dessas divergências com as fugas e demais atividades rebeldes; a obra coletiva, Liberdade por um fio. História dos quilombos no Brasil, organizada por João José Reis e Flávio dos Santos Gomes (1996), organizada por João José Reis e Flávio dos Santos Gomes (1996), que traz reflexões de vários especialistas, do Brasil e do exterior, sobre a história dos quilombos no Brasil, de norte a sul do Brasil; e a produção de Stuart Schwartz, com o livro Roceiros e rebeldes, publicado em 2001, no Brasil, que discute a escravidão e seus limites para escravos e senhores.
} 
estabelecer a diferenciação entre a Casa Grande e a Senzala, considerando a solução dada um elemento fundamental por garantir o balizamento e o sentido do enredo.

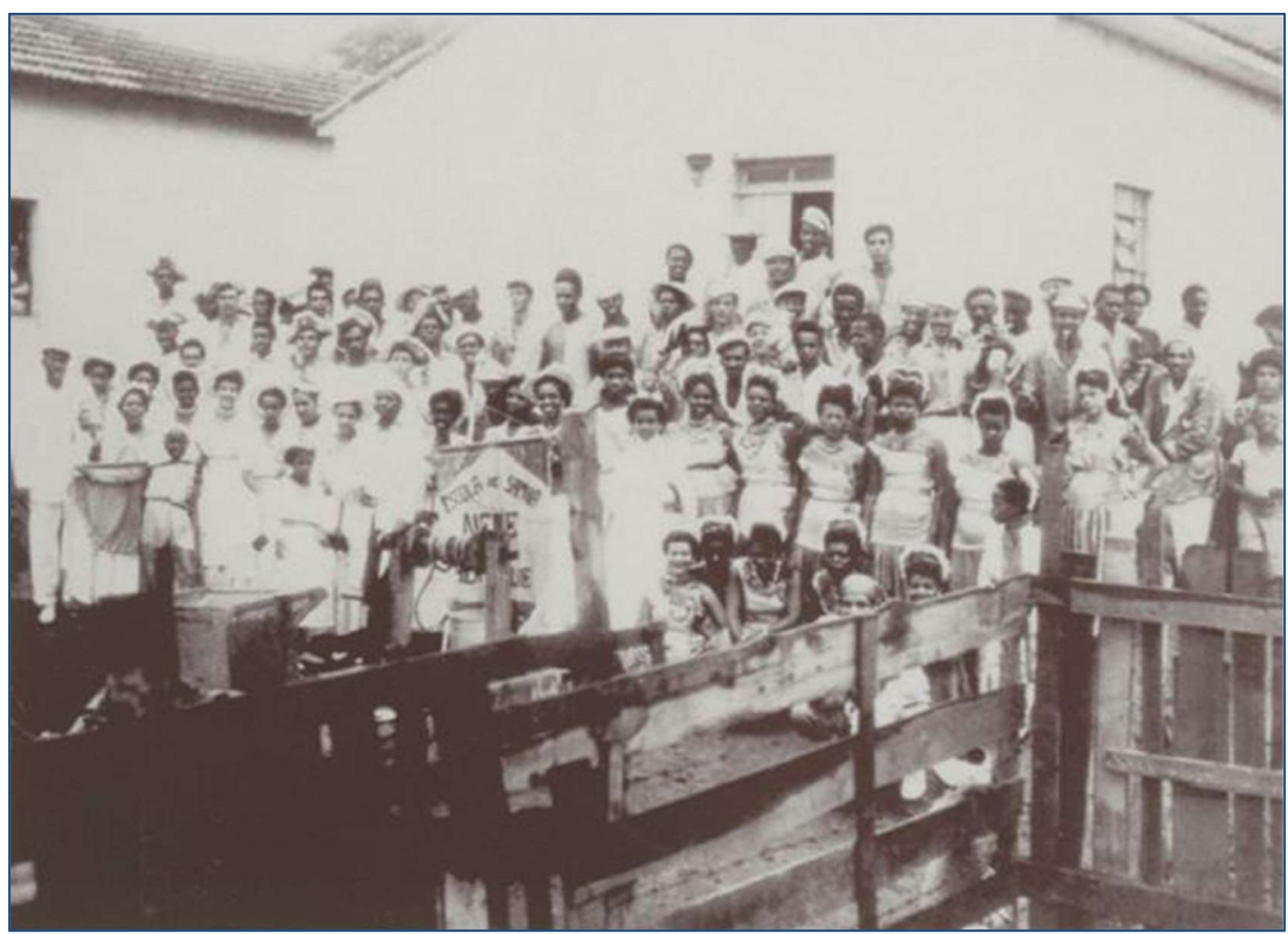

Figura 3 - Samba-Enredo: Casa Grande e Senzala - 68 componentes Desfile da Escola Nenê da Vila Matilde - 1956. Fonte: SIMSON, 2007, p.318.

No ano seguinte, a discussão foi a Lei Áurea, que, no relato de Seu Nenê (SILVA, BRAIA, 2000, p. 58), era uma “homenagem aos escravos e à Princesa Isabel”. O tema reiterava o do ano anterior, o que não foi interessante para a Escola, por ser repetitivo, admite Seu Nenê.

Assim, os desfiles dos anos seguintes foram estruturados seguindo temas históricos - O Grito do Ipiranga (1958), o Despertar de um Gigante (1960), A Marquesa de Santos (1961) —, que foram intercalados com temas afros, a exemplo de 1959 e 1962, cujos sambas-enredo foram: Chica da Silva (letra de Paulistinha e música de Popó) e A Escrava Isaura.

Voltando aos sambas-enredo afros, Chica da Silva, por exemplo, exalta a paixão despertada pela “crioula bonita” que enfeitiça o contratador João Fernandes, homem de 
confiança da Coroa portuguesa. João Fernandes acumula riquezas e compete com o próprio rei de Portugal ${ }^{28}$. Segundo a lenda, ele faz as vontades mais bizarras de Chica da Silva, até mesmo desviar o curso de um rio para ela navegar de barco.

Já o tema de A Escrava Isaura desloca-se para o século XIX, de um Brasil já independente e escravocrata. A foto do desfile de A Escrava Isaura apresenta figurantes vestidos a caráter, tendo, no centro, Tóquio, vice-presidente da Escola, cujos trajes indicam tratar-se de um homem livre, comum (SILVA, BRAIA, 2000, p. 45).

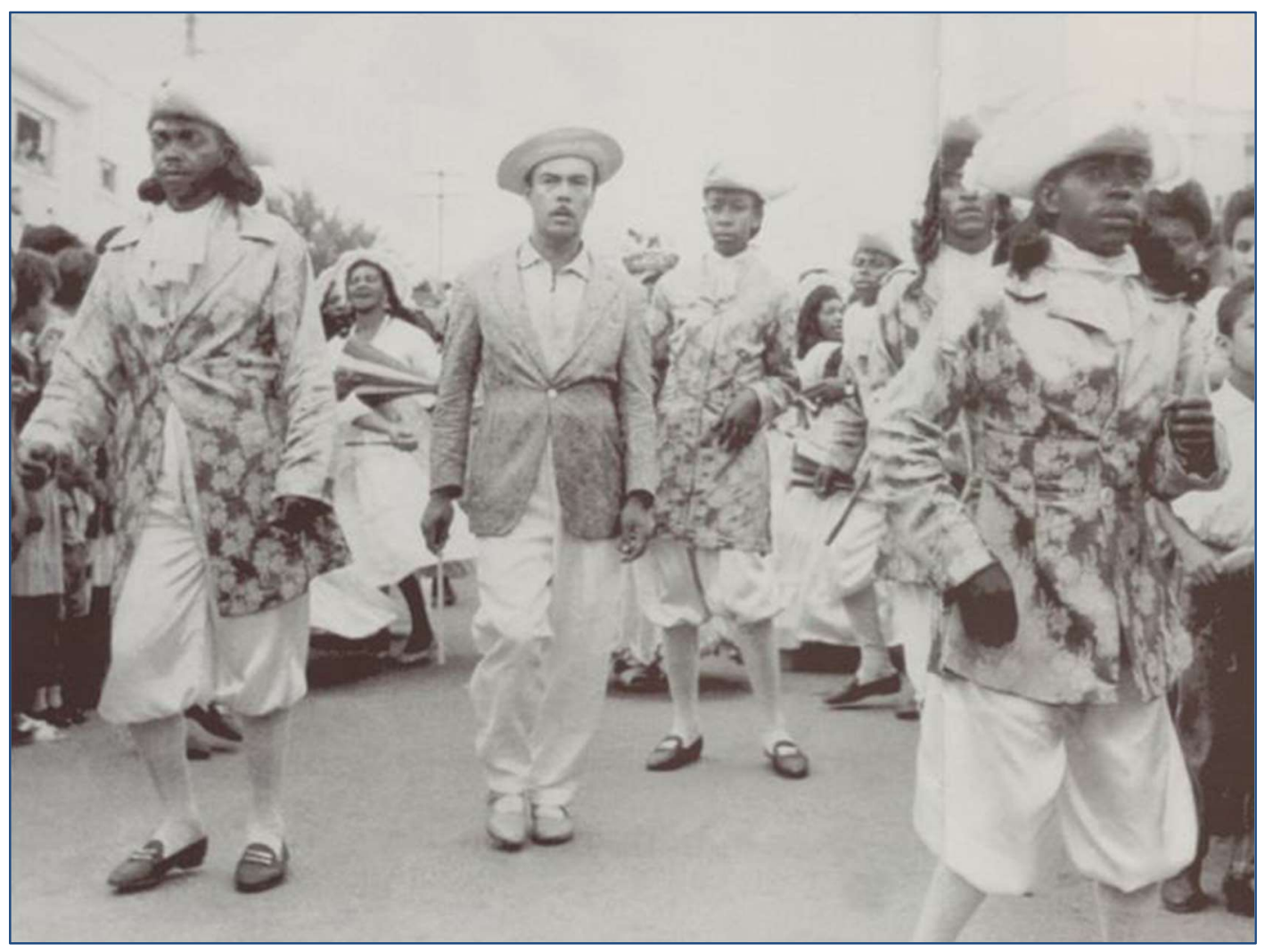

Figura 4- Samba-enredo - A Escrava Isaura Desfile da Nenê da Vila Matilde, 1962.

Fonte: SIMSON, 2007, p. 326

Os demais trajes, usados pelos integrantes masculinos da escola, são casacos estampados sobre calças brancas, meias longas ajustadas até o joelho e sapatos "estilo

\footnotetext{
${ }^{28}$ Um trecho do samba foi recuperado por Seu Nenê e diz o seguinte: "Sendo o mais livre das Minas Gerais / Sua fortuna pessoal era maior do que do rei de Portugal / E o prazer do contratador era fazer as vontades de seu grande amor" (SILVA, BRAIA, 2000, p. 110).
} 
homem livre, branco, com escrava de outro senhor. A criança - que foi criada como uma sinhazinha pelos senhores, donos de sua mãe -, ao chegar à idade adulta, sofrerá as agruras de sua condição. Por sua situação ambivalente, ao mesmo tempo escrava e moça refinada que desperta paixão aos senhores de escravos e ao filho de seu senhor (que pretende usar de suas "prerrogativas" de proprietário para possuí-la sexualmente, como procedia com as demais escravas) ${ }^{30}$, luta para conseguir sua liberdade e casar-se, conforme os cânones exigidos para as moças de elite. As promessas de liberdade, sempre adiadas por seus donos originários, não deixam outra alternativa que não a fuga, para livrar-se do cativeiro e das investidas sexuais do herdeiro. Apesar das repetidas tentativas, sempre é capturada, logrando a sua liberdade após longa epopeia de sofrimento, bem ao estilo das historietas românticas, nas quais a heroína triunfa no final da trama.

Independentemente disso, essa estória possibilita dramatização e se constitui em apelo crítico e teatral, por trazer elementos gerais que envolvem o período do cativeiro negro em toda a sua complexidade, trazendo desde a luta dos escravos, com suas fugas e organização de resistência nos quilombos, à dos antiescravistas, que se posicionam em relação à questão, engajando-se nessa luta de forma efetiva. Nesse sentido, é um tema agregador para sua encenação em desfiles carnavalescos, por não excluir desse processo as elites, tornando possível, sem muitos percalços, a crítica ao sistema escravista e o desvelamento das múltiplas faces da resistência. O impacto do desfile não pôde ser aferido, pois a imprensa não registrou (por escrito ou por fotos) a exibição do tema na Avenida São João. ${ }^{31}$

\footnotetext{
29 Pode-se dizer que é uma releitura atualizada do passado, pois não se trata de cópias dos trajes da nobreza do século XIX, seguidos pelos nobres brasileiros.

30 O romance de Bernardo Guimarães é de 1875 e ganha projeção em sua época pela postura antiescravista. No final do século XX, torna-se conhecido mundialmente, ao ser transformado em novela de televisão, editada pela Rede Globo de Televisão e pela TV Record.

${ }^{31}$ Não se tem informações sobre o impacto despertado por esse tema na Avenida São João. Sabe-se, pela Folha de S. Paulo (7/3/1962), que estavam "inscritos 10 escolas e conjuntos carnavalescos" para os desfiles na Avenida, dentre os quais Nenê da Vila Matilde.
} 
A negatividade do legado escravo sobre a comunidade explicita-se na reafirmação do valor étnico dos afrodescendentes, em Enaltecendo uma raça, mote de seu desfile de 1963. Isso deixa antever os descontentamentos da comunidade negra em relação à continuidade de sua exclusão dos circuitos diversos de funcionamento da sociedade brasileira - a exemplo da inserção desigual no mercado de trabalho, sem condições de competitividade com os demais trabalhadores brasileiros brancos, o que limita a melhoria de suas vidas em todos os níveis (ANDREWS, 1998) - e, certamente, dos preconceitos de todo tipo, enfrentados cotidianamente. Se isso não ocorresse, não haveria motivos para definir temário voltado a essa exaltação do grupo.

Não se trata de marcar, somente, situações de protestos. Os demais assuntos voltam-se ao Brasil (e procuram articular, de algum modo, São Paulo à história do país e do próprio grupo) e vão do ato fundador, com O grito do Ipiranga (samba-enredo de Paulistinha e Tóquio), a elementos que caracterizam os bastidores de sua história nos primeiros anos do Império, como A Marquesa de Santos (1961) ${ }^{32}$, fruto de pesquisas sobre o assunto, como informa Seu Nenê. Em outras palavras, pensam a trajetória do país desde o ato fundador ( $\mathrm{O}$ grito do Ipiranga) ${ }^{33}$ à contemporaneidade, a exemplo do desfile de 1960, o Despertar de um Gigante.

Cabe observar que essas incursões por temas históricos para os sambas-enredo, voltados para a identidade do país ou de São Paulo, devem ser lidas a partir das percepções de Tóquio e Paulistinha (e da diretoria da escola), que recriam, à sua maneira, os eventos em si. Certamente a falta de acesso ao conteúdo dos enredos impôs limites às reflexões por inibir a apreensão das visões de mundo do grupo, presentes nessas representações. Essa situação foi minorada pela localização das fotos de alguns dos desfiles exibidos nos carnavais da cidade que permitiram visualizar as indumentárias e esculturas dos carros alegóricos que tematizaram o assunto, possibilitando a apreensão de seus possíveis sentidos.

\footnotetext{
32 Tóquio foi o autor de vários sambas-enredo da Nenê. Os sambas-enredo Marquesa de Santos e Carlos Gomes foram de sua autoria. "Pegava um livro, lia e criava as histórias", informa Seu Nenê, lembrando que "ele era um menino danado, talentoso, mexia com a cabeça das pessoas" (SILVA, BRAIA, $2000, \mathrm{p}$. 45). O samba-enredo O grito do Ipiranga foi de sua autoria e de Paulistinha (SILVA, BRAIA, 2000, p. 58).

33 Não foram localizados samba-enredo e fotos sobre O Grito do Ipiranga. Por essa razão, a análise do assunto foi incorporada aos temas que se voltam para dimensões históricas do país.
} 
Exemplos disso são os desfiles de 1960 e 1961 da Escola, cujos registros são apenas as fotos. Em 1960, a agremiação traz Despertar de um Gigante que tematiza o Brasil contemporâneo. O carro alegórico projeta, simbolicamente, uma "torre de Petróleo", em cuja lateral se vê escrito "Brasília", a indicar a fundação da nova capital. Essas representações enfatizam os símbolos do "progresso" do país e instauração de nova realidade, celebrados de forma ufanista no título do próprio tema, deixando para trás o seu passado de promessas do vir a ser.

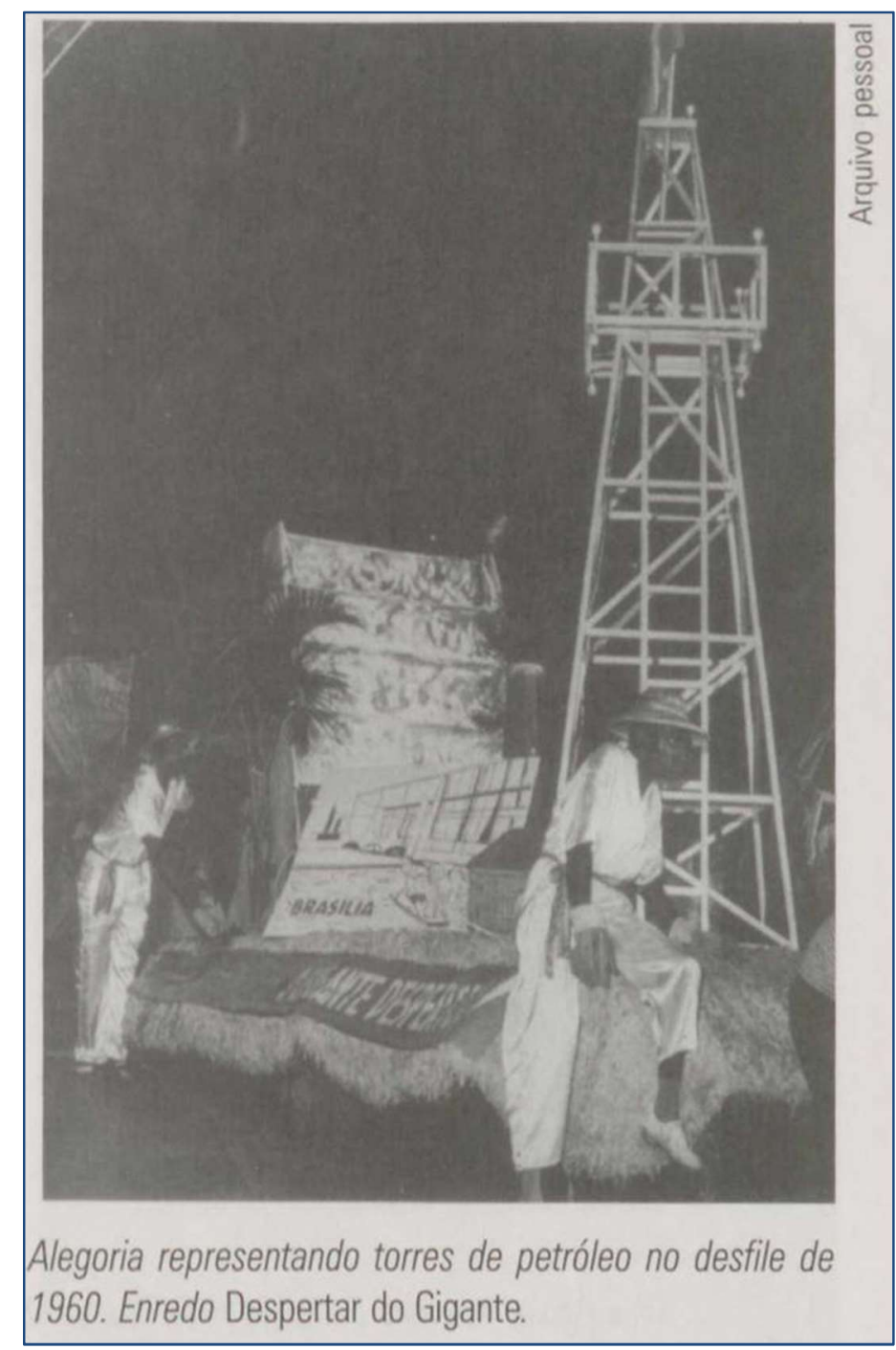

Figura 5 - Despertar de um Gigante - 1960

Desfile da Escola de Samba Nenê da Vila Matilde (1960). Fonte: SIMSON, 2007, p. 337.

No ano seguinte, a passeata da escola sobre a Marquesa de Santos, evidencia-se em duas fotos: a do carro alegórico que traz a "coroa da Marquesa" no centro do 
monumento, e a do casal principal que personifica D. Pedro I e a Marquesa de Santos. Esse material ratifica possibilidades de incursões sobre aspectos dessa proposta, a exemplo dos trajes que aparecem como simulacros dos protagonistas reais e a possível releitura dos carnavalescos sobre o assunto. Os trajes, por exemplo, buscam alguma similitude com os heróis que serviram de inspiração. A Marquesa porta uma veste de renda com muitos babados na saia, luvas, "colar de pérola", tiara real e um leque ornamentado. Já a personagem de Pedro I aparece em trajes elegantes (sobrecasaca bordada), em contraste ao traje branco, que inclui peruca, coroa, luvas, meias e sapato afivelado. Entretanto, o desafiador é a percepção dos carnavalescos sobre a Marquesa favorita do Imperador, que, ao trazerem para avenida a história amorosa de ambos, redefinem os papéis vividos por aquela mulher, que na representação deixa de ser a amante clandestina e torna-se, simbolicamente, a imperatriz ausente, leitura essa demonstrada pela coroa (sem protagonista) do principal carro alegórico do enredo.

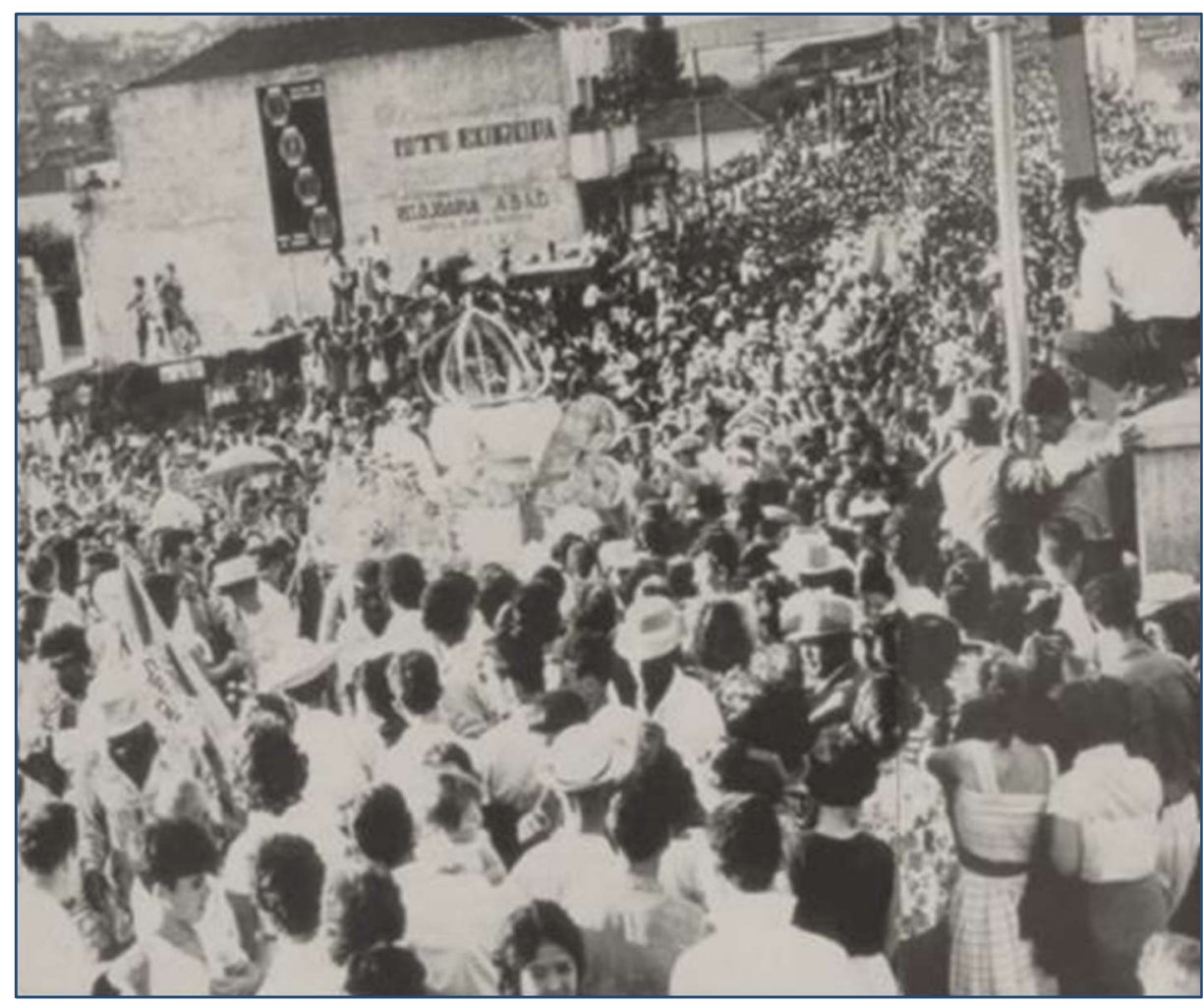

Figuras 6 - Samba enredo: A Marquesa de Santos Desfile da Escola de Samba Nenê da Vila Matilde (1961).

Fonte: SIMSON, 2007, p. 321. 


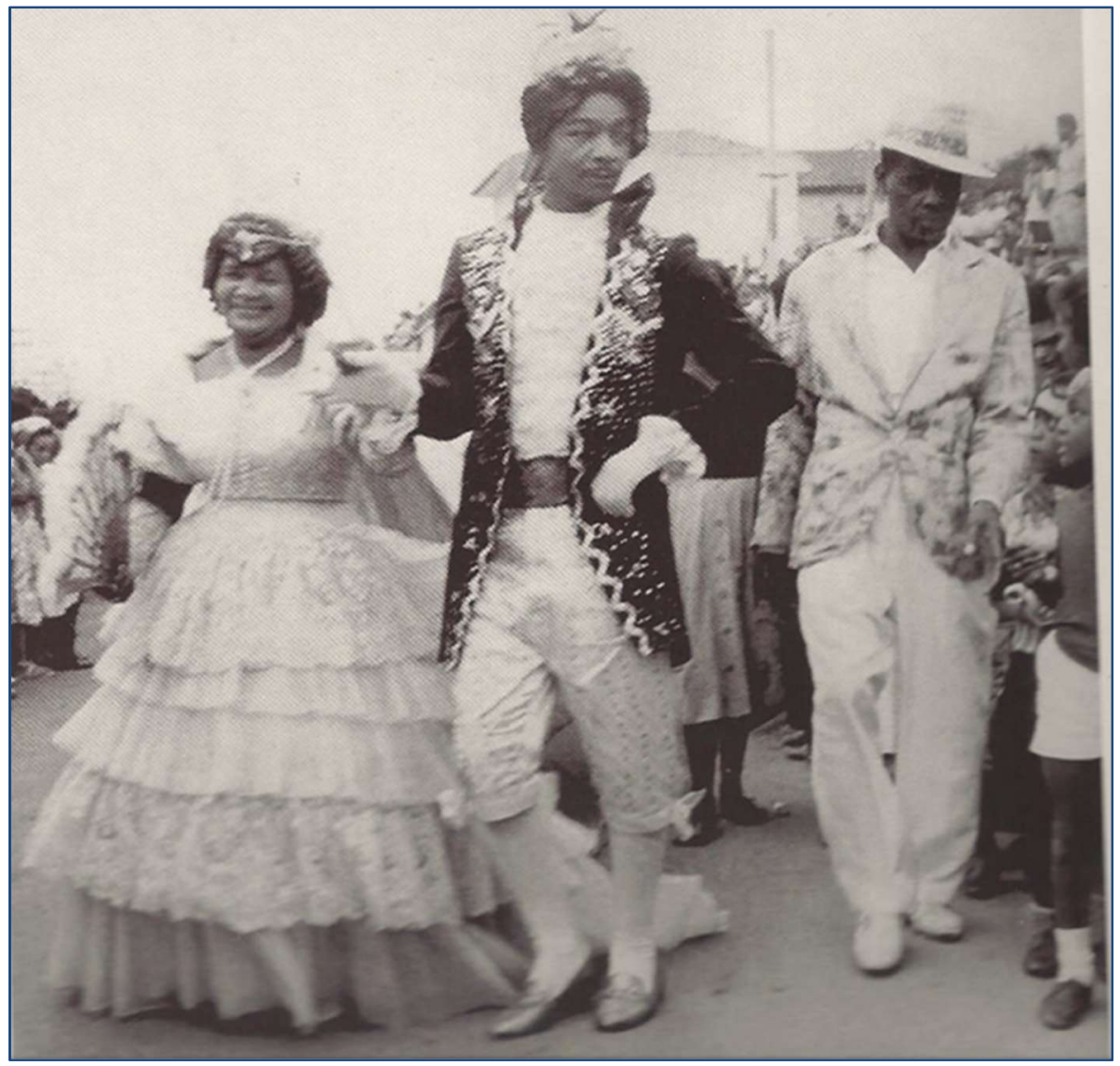

Figuras 7 - Samba enredo: A Marquesa de Santos Desfile da Escola de Samba Nenê da Vila Matilde (1961). Fonte: SIMSON, 2007, p.322.

Além dos temas apresentados acima, foram propostos outros que recuaram ainda mais no tempo, para rememorar a epopeia bandeirante dos setecentos, com a homenagem a Paes Leme, o Bandeirante (1964) e O Tronco do Ipê (1967), romance (ambientado no norte fluminense, produtor de café, mas já decadente), escrito por José de Alencar.

As encenações carnavalescas, em 1964, voltadas ao tema Paes Leme, o Bandeirante, trazem o carro alegórico que marca a trajetória do controvertido bandeirante paulista "caçador de Esmeraldas" e alargador de fronteiras, mas também "caçador de índios", submetendo-os à escravização. O jornal O Estado de S. Paulo limitou-se a informar que, em Vila Esperança, "haverá desfile de carros alegóricos apresentando motivos de épocas passadas" (O Estado de S. Paulo, 8/2/1964, p. 19). Mas o jornal Folha de S. Paulo divulga que ocorreram desfiles programados na Lapa, patrocinados pelo Clube dos Lojistas locais, que financiou várias escolas de samba com 
quantias relativamente vultosas, visando à elaboração das fantasias requeridas para as exibições dessas escolas. 34

Nessa mesma linha de reafirmação de identidade do país, em 1967, inscreve-se 0 Tronco do Ipê (Figura 8), tema que celebra um de seus mais importantes escritores românticos, José de Alencar, intelectual de projeção, conforme exploram os estudiosos de sua produção35, identificado com a defesa desses ideais de demarcação dos traços do país e de sua nacionalidade.

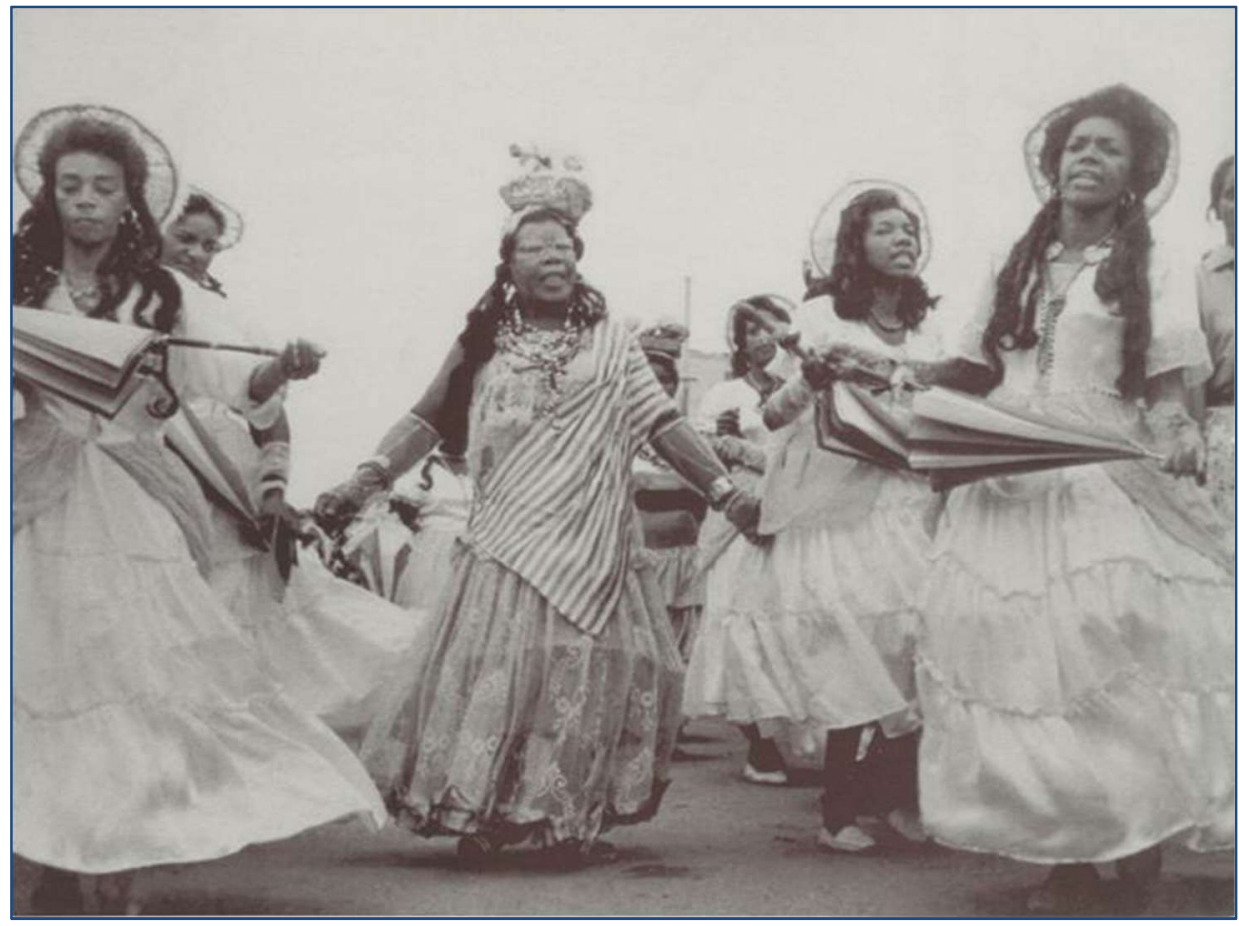

Figura 8 - O Tronco do Ipê - Desfile da Escola de Samba Nenê da Vila Matilde (1961). Fonte: SIMSON, 2007, p.334.

$\mathrm{Na}$ foto, fragmento desse momento, a representação do assunto aparece expressa na alegórica Ala das Pastoras ${ }^{36}$, confundindo-se a tradição afro e o simbolismo representado pelo romance, exibido no enredo carnavalesco.

\footnotetext{
${ }^{34}$ Segundo o jornal Folha de S. Paulo desfilaram nesse carnaval lapeano os cordões XV de Novembro e VaiVai, saindo da Bela Vista com 200 figurantes, e as escolas de samba "Unidos do Peruche, com 800 figurantes, Unidos do Morro de Vila Maria, Nenê da Vila Matilde, Coração de Bronze, Lavapés, Acadêmicos de Vila Jaguará, Império do Samba e Império do Cambuci” (Folha de S. Paulo, 11/2/1964).

35 Os estudiosos de sua obra são muitos - vão de Antonio Cândido a Nelson Werneck Sodré, conforme cita Marcelo Peloggio (2004) no texto "José de Alencar: um historiador à sua maneira", publicado na revista ALEA.

${ }^{36} \mathrm{Em}$ alguns registros bibliográficos, há menção, para esse período, sobre a existência nos desfiles da "Ala das Baianas". Porém, parece ser mais apropriado falar de "Ala das Pastoras", como faz Simson (2007, p.
} 
Encerrando essas reflexões, diria que ao trazer para os espaços públicos os seus desfiles temáticos sob a batida do samba, a Nenê viveu a experiência e as dificuldades de estruturar os desfiles, colocando em cena os carros alegóricos, o que implicava resolver impasses de todo tipo, desde a falta de recursos para sua montagem às estratégias para movimentar as alegorias durante os desfiles. Ao mesmo tempo, essa trajetória da Nenê (desfilando nos carnavais da cidade, pautada por samba-enredo desde 1956), a colocava numa situação privilegiada ante as demais agremiações após a oficialização dos carnavais em 1968. Essas experiências da Nenê eram diferentes dos cordões Camisa Verde e Branco e Vai-Vai, os quais possuíam estrutura de desfiles diversa à das escolas de samba, embora contassem com músicos e instrumentistas. O "batuque e músicas" de seus desfiles não era o do samba, e sim apoiado nas "marchas sambadas", conforme esclarece Wilson de Moraes (1978).

Em depoimento, Amaral admite que a passagem do cordão Vai-Vai para Escola de Samba, em 1971, não foi simples. A “dificuldade foi controlar a bateria que ainda (era) muito pesada. Tinha noção de como funcionava uma escola. Já tinha introduzido as alas. O difícil era a porta-bandeira. A ‘corte' acabou. E tinham os sambas-enredo exigidos para os desfiles" (Fita 112.31-32 - Carnaval Paulistano -MIS/SP- AMARAL - Entrevista concedida em 02/10/1981).

\section{Considerações finais}

As reflexões desenvolvidas neste texto têm relevância especial por trazerem alguns elementos que permitem esclarecer aspectos que já estavam presentes nas escolas de samba paulistanas, antes mesmo do processo de institucionalização, em 1968. Exemplo disso é a existência de samba-enredo e de temas que, embora apareçam naturalizados, estiveram presentes nas performances carnavalescas exibidas na cidade desde o ano de 1954, trazidos pela Escola de Samba Nenê da Vila Matilde, com o tema Zumbi dos Palmares.

334), considerando o perfil e a montagem dessa estrutura que se vincula à tradição dos cordões. 
Isso significa que as alterações já estavam em curso quando as principais lideranças dessas agremiações solicitam ao Prefeito da capital, Faria Lima37, a sua institucionalização, objetivando resolver a questão da falta de recursos para a montagem dos desfiles, de acordo com as exigências requeridas pelos temas de suas escolhas, que exigiam a incorporação do trabalho de profissionais especializados para a montagem das alegorias e esculturas carnavalescas.

Cabe ainda assinalar que, no período ditatorial, os temas dos sambas-enredo voltaram-se para assuntos gerais da história do país ou da literatura, diferentemente do período anterior, em que prevaleceram assuntos mais críticos e voltados ao universo dos afrodescendentes - seja no período da escravidão, seja na atualidade -, com a escolha de letras de música de sucesso que nem sempre centravam-se no universo lírico amoroso do cancioneiro popular, a exemplo de "Lata d'agua", que tematizava a difícil vida de uma mulher que carregava, morro acima (favela), na cabeça, a água que necessitava em seu dia a dia, sugerindo que era "lavadeira de roupa" para o seu sustento e de sua família.

Enfim, assuntos que, de uma forma ou de outra, traziam o universo de seus protagonistas, fazendo, eles próprios, uma releitura de suas agruras ao representar aquele universo, vivendo os seus próprios papéis e os de seus senhores, que os submeteram ao cativeiro. Essas representações expressam o coroamento e o descoroamento de seu mundo, numa espécie de paródia da vida ordinária, de antes e de então, tal qual reflete Bakhtin (1987). Ou no período após a abolição, que igualmente trazem temas os quais, sub-repticiamente, desvelam a continuidade da submissão a situações de exclusão e abandono, expostos nos desfiles exibidos na avenida durante esses folguedos momescos.

\footnotetext{
37 José Vicente Faria Lima, nascido em 1909 no Rio de Janeiro, era engenheiro militar especializado na área de aviação. Ficou conhecido na cidade de São Paulo por ter integrado a Secretaria de Viação e Obras Públicas, na gestão de Jânio Quadros, coordenando várias obras relativas ao traçado e alargamento das ruas da capital. Foi eleito Prefeito da cidade para o período de janeiro de 1965 a abril de 1969, substituindo Francisco Prestes Maia (SILVA, 2008). Faleceu em 4 de setembro de 1969.
} 


\section{Referências}

ALENCAR, Edigard de. O Carnaval carioca através da música. 5. ed. Rio de Janeiro: Francisco Alves; Brasília: INL, 1985.

AMARAL, Sebastião Eduardo. Depoimento. São Paulo: Museu da Imagem e do Som-MIS, 1981. Entrevista concedida ao Projeto Carnaval Paulistano do MIS/SP, em 02 outubro de 1981, (Fita 112.31-32).

AUGRAS, Monique. O Brasil do Samba-Enredo. Rio de Janeiro: Editora Fundação Getúlio Vargas, 1998.

ALBERTI, Verena. Fontes Orais: Histórias dentro da História. In: Pinsky, Carla Bassanezi. Fontes orais. São Paulo: Contexto, 2005. p. 155-202.

AZEVEDO, Célia Maria Marinho de. Onda negra, medo branco. O negro no imaginário das elites: século XIX. Rio de Janeiro: Paz e Terra, 1987.

ANDREWS, George Reid. Negros e brancos em São Paulo (1888-1988). Bauru/SP: EDUSC, 1998.

BARONETTI, Bruno Sanches. Da oficialização ao sambódromo: um estudo sobre as escolas de samba de São Paulo (1968-1996). 2013, 397f. Dissertação (Mestrado) Universidade de São Paulo, Faculdade de Filosofia, Ciências e Letras, São Paulo, 2013.

BAKHTIN, Mikhail. A cultura popular na idade média e no renascimento. São Paulo: HUCITEC/UnB, 1987.

BEZERRA, Danilo Alves. A trajetória da internacionalização dos carnavais do Rio de Janeiro: as escolas de samba, os bailes e as pândegas das ruas (1946-1963). 2016, 287f. Tese (Doutorado) - Universidade Estadual Paulista Júlio de Mesquita Filho, Faculdade de Ciências e Letras, São Paulo, 2016.

BRITTO, leda Marques. Samba na cidade de São Paulo (1900-1930): um exercício de resistência cultural. São Paulo: FFLCH/USP, 1986.

CORREIO PAULISTANO, São Paulo, 1953 a 1957.

DOZENA, Alessandro. As territorialidades do samba na cidade de São Paulo. 2009, Tese (Doutorado) - Universidade de São Paulo, Faculdade de Filosofia, Ciências e Letras, São Paulo, 2009. 
FOLHA DA MANHÃ, São Paulo, 1950 a 1959.

GOMES, Flávio dos Santos. De olho em Zumbi dos Palmares. São Paulo: Editora Companhia das Letras, 2011.<https://pt.ikipedia.org/wiki/Nen\%C3\%AA_de_Vila_Matilde>. Acesso em: 19 set. 2015.

LOPES, Maria Aparecida de Oliveira. História e memória do negro em São Paulo: efemérides, símbolos e identidade (1945-1978). 2007, Tese (Doutorado em História) Universidade Estadual Paulista Júlio de Mesquita Filho, Faculdade de Ciências e Letras Assis, 2007.

LUCA, Tânia Regina de. Fontes impressas: História dos, nos e por meio dos periódicos. In: PINSKY, Carla Bassanesi; LUCA, Tânia Regina de (Orgs.). O historiador e suas fontes. São Paulo: Contexto, 2005. p. 111-153.

MADRE, Diolinda. Depoimento. Entrevistadores: Silvio Ferreira Faro e Olga Rodrigues de Moraes von Simson. São Paulo: Museu da Imagem e do Som-MIS, 1982. Entrevista concedida ao Projeto Carnaval Paulistano do MIS/SP. (Fita 112.25).

MORAES, Wilson R. Escolas de Samba de São Paulo. São Paulo: IMESP, 1978.

NAZARETH, Zezinho. Depoimento. Entrevistadora - Olga Rodrigues de Moraes von Simson. São Paulo: Museu da Imagem e do Som/MIS/SP- [1980]. Projeto Carnaval Paulistano, (Fita 112.4-5).

O ESTADO DE S. PAULO. São Paulo - 1950 a 1954; 1958.

PELOGGIO, Marcelo. José de Alencar: um historiador à sua maneira. ALEA: Rio de Janeiro, v. 6, n. 1, p. 81-95, jan.-jun., 2004.

PROPP, Vladimir. Comicidade e riso. São Paulo: Ática, 1992.

REIS, João José; GOMES, Flávio dos Santos. Liberdade por um fio. História dos quilombos no Brasil. São Paulo: Companhia das Letras, 1996.

SILVA, Zélia Lopes da. Os carnavais de rua e dos clubes na cidade de São Paulo. Metamorfoses de uma festa (1923-1938). São Paulo: Editora UNESP; Londrina: EDUEL, 2008.

SILVA, Zélia Lopes da. A memória dos carnavais dos afro-paulistanos na cidade de São Paulo nas décadas de 20 e 30 do século XX. Diálogos [ online], Maringá, v. 16, Supl. Espec., p.37-68, dez. 2012. Disponivel em: 
http://www.uem.br/dialogos/index.php?journal=ojs\&page=article\&op=view\&path\%5B\%5D $=709$

SILVA, Alberto Alves, BRAIA, Ana. Memórias do Seu Nenê da Vila Matilde. São Paulo: Lemos Editorial, 2000.

SIMSON, Olga Rodrigues de Moraes von. Carnaval em branco e negro. São Paulo: EDUSP, 2007.

SCHWARTZ, Stuart. Roceiros e rebeldes. Bauru: Edusc, 2001.

Recebido em 17/11/2015 Aprovado em 11/08/2016 